\title{
Molecular basis of carrageenan-induced cytokines production in macrophages
}

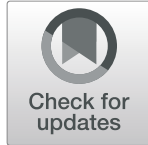

\author{
Alexandre H. Lopes ${ }^{1}$, Rangel L. Silva' ${ }^{1}$, Miriam D. Fonseca' ${ }^{1}$, Francisco I. Gomes', Alexandre G. Maganin ${ }^{1}$, \\ Lucas S. Ribeiro ${ }^{2}$, Lucas Maciel Mauriz Marques ${ }^{3}$, Fernando Q. Cunha', Jose C. Alves-Filho ${ }^{1}$, Dario S. Zamboni ${ }^{4}$, \\ Norberto P. Lopes ${ }^{3}$, Bernardo S. Franklin², Aurélie Gombault ${ }^{5}$, Fernando Silva Ramalho ${ }^{6}$, Valerie F. J. Quesniaux ${ }^{5}$, \\ Isabelle Couillin ${ }^{5}$, Bernhard Ryffel ${ }^{5}$ and Thiago M. Cunha ${ }^{1 *}$ (D)
}

\begin{abstract}
Background: Low molecular weight carrageenan $(\mathrm{Cg})$ is a seaweed-derived sulfated polysaccharide widely used as inflammatory stimulus in preclinical studies. However, the molecular mechanisms of $\mathrm{Cg}$-induced inflammation are not fully elucidated. The present study aimed to investigate the molecular basis involved in $\mathrm{Cg}$-induced macrophages activation and cytokines production.

Methods: Primary culture of mouse peritoneal macrophages were stimulated with Kappa Cg. The supernatant and cell lysate were used for ELISA, western blotting, immunofluorescence. Cg-induced mouse colitis was also developed.

Results: Here we show that $\mathrm{Cg}$ activates peritoneal macrophages to produce pro-inflammatory cytokines such as TNF and IL-1 $\beta$. While Cg-induced TNF production/secretion depends on TLR4/MyD88 signaling, the production of pro-IL-1 $\beta$ relies on TLR4/TRIF/SYK/reactive oxygen species (ROS) signaling pathway. The maturation of pro-IL1 $\beta$ into $\mathrm{IL}-1 \beta$ is dependent on canonical NLRP3 inflammasome activation via Pannexin-1/P2X7/K $\mathrm{K}^{+}$efflux signaling. In vivo, Cg-induced colitis was reduced in mice in the absence of NLRP3 inflammasome components.
\end{abstract}

Conclusions: In conclusion, we unravel a critical role of the NLRP3 inflammasome in Cg-induced pro-inflammatory cytokines production and colitis, which is an important discovery on the pro-inflammatory properties of this sulfated polysaccharide for pre-clinical studies.

Keywords: Carrageenan, Macrophages, IL-1ß, NLRP3 Inflammasome, Pannexin-1 channel

\section{Background}

Carrageenan $(\mathrm{Cg})$ is a seaweed-derived sulfated polysaccharide $[1,2]$. There are three major forms of carrageenan: lambda- $(\lambda)$, kappa- $(\kappa)$ and iota- $(\iota)[3,4]$. There is evidence that chronic ingestion of some subtypes of $\mathrm{Cg}$, especially low-molecular weight, is associated with inflammation, intestinal cancer and ulcerations [5-7].

\footnotetext{
* Correspondence: thicunha@fmrp.usp.br; thicunha@usp.br

'Department of Pharmacology, Ribeirão Preto Medical School, University of

São Paulo, Center for Research in Inflammatory Diseases (CRID)Av.

Bandeirantes 3900, 14049-900, Ribeirão Preto, SP, Brazil

Full list of author information is available at the end of the article
}

Furthermore, these flogistic Cg subtypes are extensively used to induce inflammation in several experimental animal models especially to study novel anti-inflammatory and analgesic drugs [8-11]. For instance, Cg injected into the rodents hindpaw causes a classical innate immune response characterized by paw oedema, neutrophil migration and pain [12, 13].

Our group has identified that $\mathrm{Cg}$-induced inflammation and inflammatory symptoms are dependent on activation of macrophages through the production of proinflammatory cytokines, especially TNF and IL-1 [14-16]. In vitro, $\mathrm{Cg}$ induces peritoneal macrophages activation and

(c) The Author(s). 2020 Open Access This article is licensed under a Creative Commons Attribution 4.0 International License, which permits use, sharing, adaptation, distribution and reproduction in any medium or format, as long as you give appropriate credit to the original author(s) and the source, provide a link to the Creative Commons licence, and indicate if changes were made. The images or other third party material in this article are included in the article's Creative Commons licence, unless indicated otherwise in a credit line to the material. If material is not included in the article's Creative Commons licence and your intended use is not permitted by statutory regulation or exceeds the permitted use, you will need to obtain permission directly from the copyright holder. To view a copy of this licence, visit http://creativecommons.org/licenses/by/4.0/. The Creative Commons Public Domain Dedication waiver (http://creativecommons.org/publicdomain/zero/1.0/) applies to the data made available in this article, unless otherwise stated in a credit line to the data. 
the production of these pro-inflammatory cytokines [17, 18]. In regards to the possible molecular mechanisms, there is evidence that seaweed-derived polysaccharides can regulate the innate immune response directly through the binding of pattern recognition receptors (PRRs), such as mannose and Toll-like receptors (TLR) in phagocytic cells, including macrophages [19-22]. Precisely, Cg activates TLR4 in vitro $[18,23,24]$ and induces processing of proIL-1 $\beta$ into mature IL-1 $\beta$ dependently on caspase-1 (Casp1) activation in vivo [25].

However, the exact molecular mechanisms of $\mathrm{Cg}$ induced macrophages activation and pro-inflammatory cytokines production remains to be demonstrated. Herein, we set out to clarify the molecular mechanisms involved in macrophages activation by $\mathrm{Cg}$, focusing on the intracellular pathways for IL- $1 \beta$ production/release. We demonstrate that peritoneal macrophages from naïve mice produce both forms of pro-inflammatory IL$1 \beta$ when stimulated with $\mathrm{Cg}$ alone. Furthermore, we provided evidence that $\mathrm{Cg}$-stimulated macrophages produce pro-IL-1 $\beta$ depends on TLR4/TRIF/Syk/ROS, whereas it's processing into mature IL-1 $\beta$ requires activation of the canonical NLRP3 inflammasome. Finally, we show that NLRP3 inflammasome is implicated in Cg-induced colitis in mice. These data unravel the previous unknown molecular basis for IL- $1 \beta$ production by Cg-stimulated macrophages and in vivo inflammation.

\section{Methods}

\section{Animals}

The experiments were performed using six to eightweek-old-male weight ( $25 \mathrm{~g}$ ) wild type (WT) C57BL/6 mice (Jackson Laboratory, stock number 000664) and deficient $\left(^{-/-}\right)$mice in the following genes: $N \operatorname{lrp} 3^{-/-}$, Casp1/11 ${ }^{-/-}$, Casp1 $^{-/-}$Casp11Tg, Nlrc4 ${ }^{-1-}$, Pycard $^{-1-}$ (ASC) derived from C57BL/6 mouse strains. The ASCmCitrine reporter mice were generated following a strategy previously described [26]. $T l r 2^{-1-}, T l r 3^{-1--}, T l r 4^{-1-}$, $\mathrm{Tlr5}^{-/-}, \mathrm{Cd}_{14^{-1-}}, \mathrm{Trif}^{-1-}, \mathrm{Myd} 88^{-/-}$. Panx $\mathrm{1}^{-/-}$mice were kindly provided by Dr. Valery Shestopalov (University of Miami). All strains were maintained at the animal facility of the Ribeirão Preto Medical School, University of São Paulo (São Paulo, Brazil). P2rx $7^{-1-}$ mice were obtained from the Immunology and Experimental Neurogenetics at the National Center for Scientific Research (CNRS) University of Orléans - France by Dr. Bernhard Ryffel and Dra. Isabelle Couillin. Breeding pairs of mice with targeted disruptions of all genes were maintained/backcrossed with $\mathrm{C} 57 \mathrm{BL} / 6$. Animal care and handling procedures were performed in accordance with the current guidelines in accordance with Ethics Committee on Animal Experimentation of the Ribeirão Preto Medical School, University of São Paulo.

\section{Reagents}

The following reagents were used in this study: Lipopolysaccharide (ultrapure LPS), N-Acetyl-L-cysteine (NAC - A7250, Sigma Aldrich), Carbenoxolone (CBX C4790, Sigma Aldrich), Nigericin (Nig - N7143, Sigma Aldrich). The Kappa-Carrageenan ( $\mathrm{Cg})$ was obtained from BDH Biochemicals (Poole, England Cat. $n^{\circ} 38,100$ ). The concentration used for the in vitro experiments range from $30 \mu \mathrm{g} / \mathrm{ml}$ up to $300 \mu \mathrm{g} / \mathrm{ml}$. $\mathrm{KCl}$ (Cat. $\mathrm{n}^{\circ}$. 7447-40-7, Labsynth), Caspase-1 inhibitor (Calbiochem, Cat. $n^{\circ} .400,010$ ), Syk inhibitor (Millipore, Cat. $n^{\circ}$. 574,711).

\section{Isolation and culture of peritoneal macrophages}

Macrophages were extracted by washing the peritoneal cavity of health animals. The total contents of the peritoneal lavage were centrifuged at $450 \mathrm{~g}$ for $8 \mathrm{~min}$, then the cell pellet was resuspended in complete RPMI medium containing $10 \%$ fetal bovine serum, $2.38 \mathrm{~g} / \mathrm{L}$ Hepes (Sigma), 100,000 U/L Penicillin/Gentamycin (Sigma), 1 g/L Streptomycin (Sigma), 2.2 g/L Sodium Bicarbonate PA (Merck). Then cell concentration was determined and subsequently distributed into stereo plates and incubated at $37{ }^{\circ} \mathrm{C}$ overnight. Non-adherent and dead cells were removed by gentle washed with RPMI medium. The remaining cultured cells were at least $97 \%$ macrophages and trypan blue exclusion test showed viability higher than $95 \%$. The cells were cultured in 96 well plate $2 \times 10^{5}$ cells/well for further ELISA assays, or in 6-well plate $2 \times 10^{6}$ cells/well for western blotting. After the treatments the supernatant and the cell lysate were collected and prepared for molecular analysis.

\section{Enzyme-linked immunosorbent assays (ELISA)}

Colon tissue or supernatant from cultured peritoneal macrophages were used to determine the levels of IL- $1 \beta$ (R\&D systems, cat. DY401-05) and TNF (R\&D systems, cat. DY4 10-05) by ELISA according to the manufacturer instructions. The results were expressed in picograms of the respective cytokine per milliliter.

\section{MTT assay}

Cell viability was determined by MTT assay adapted from Mosmann [27]. After the cell treatments, MTT (Thiazolyl Blue Tetrazolium Bromide - M2128, SigmaAldrich) at $2,5 \mathrm{mg} / \mathrm{ml}$ was added in the 96 -well plate containing the attached macrophages. After overnight incubation at $37^{\circ} \mathrm{C}$, the stain was diluted with $50 \mu \mathrm{L}$ DMSO/acid acetic and was incubated $2 \mathrm{~h}$ at $37^{\circ} \mathrm{C}$. The absorbance of each well was then measured using a microplate reader at $592 \mathrm{~nm}$, and the viability of cells was presented as absorbance value. Each treatment was replicated at least four times. 


\section{Assay for endotoxin detection}

ToxinSensor $^{\text {ma }}$ Single Test Kit (Cat. N ${ }^{\circ}$. L00447-40, GenScript) was used to detect contaminants, such as endotoxins in the carrageenan. Vehicle or samples with different concentrations of the carrageenan were incubated for $1 \mathrm{~h}$ with the kit reagent. The presence of endotoxin causes gelation and in the absence of endotoxin no gelation occurs.

\section{Quantification of reactive oxygen species (ROS)}

Dichlorofluorescein diacetate (CM-H2DCFDA, Cat. C6827, Invitrogen) was used as a fluorescent marker to detect the production of reactive oxygen species (ROS). Briefly, 30 min before carrageenan stimulation $\left(\mathrm{T}_{0}\right)$, the isolated cells were incubated with the $5 \mathrm{mM}$ H2DCFDA probe, then after $30 \mathrm{~min}$ incubation at $37^{\circ} \mathrm{C}$, the cells were washed twice in PBS. During all procedures, cells were kept protected from light to prevent loss of fluorescence. The results were quantified by using a fluorimeter apparatus (FlexStation 3, Molecular Devices).

\section{Il1b gene expression: mRNA extraction and quantitative Real-time Polymerase Chain Reaction (qRT-PCR)}

The $I l 1 b$ mRNA was determined by qRT-PCR. Samples from macrophages were lysed and the total cellular RNA was extracted as instructed by Qiagen's RNeasy Mini Kit (Invitrogen Life Technologies Corporation) and RNA concentration was determined using Genequant apparatus (Amershan Biosciences Corp., Piscataway). mRNA was reversely transcribed into cDNA using High Capacity cDNA Reverse Transcription kit (Life Technologies). qRT-PCR was performed in Step One Plus Real-Time PCR System using the SYBR-green ${ }^{\circ}$ fluorescence system (Applied Biosystems) for the quantification of amplifications. The results were analyzed using the comparative method of 2 $\Delta \Delta$ cycle threshold $(\mathrm{CT})$. The following primer sequences were used: Gapdh forward 5'-GGGTGTGAACCACGAG AAAT-3', Gapdh reverse 5'-CCTTCCACAATGCCAA AGTT-3'; Illb forward 5'TGACAGTGATGATGAGAATGACCTGTTC-3'; Il1b reverse 5'-TTGGAAGCAG CCCTTCATCT-3'. All primers were supplied by Sigma.

\section{Endogenous caspase-1 activity using FAM-YVAD- fluoromethyl ketone (FMK)}

Peritoneal macrophages into coverslips or 96 well plate were treated with carrageenan were incubated $45 \mathrm{~min}$ with FAM-YVAD-FMK (1,5 ratio) (Immunochemistry Technologies; Cat. n. 98) as recommended by the manufacturer's instructions. Cells were washed with sterile PBS at room temperature twice. The coverslips were inverted in assembly medium containing DAPI (DAPI Prolong Gold ${ }^{\circ}$ antifade reagent, invitrogen) on the fluorescence slides for subsequent capture of the images, acquired on confocal microscope (Leica TCS SP5). Caspase-1 activity was also analyzed by flow cytometry (BD FACS Verse) considering FLICA-positive cells.

\section{ATP quantification}

The supernatant from the carrageenan-stimulated cells was collected and the ATP quantification assay was immediately performed. The concentration of ATP was determined by bioluminescence according to ATP lite One-step kit recommendations (ATP Dosage Kit -6, 016,941, Perkin-Elmer, Waltham, MA, USA). The ATP lite assay system is based on the production of light elicited by the reaction of ATP with added luciferase and Dluciferin. ATP concentrations were determined using the standard curve for quantification of the samples.

\section{Western blotting}

Cells were lysate in protein extraction buffer containing protease inhibitor, while the supernatants were prepared by precipitation of proteins using chloroform/methanol. IL-1 $\beta$ immature (pro-IL-1 $\beta ; \sim 35 \mathrm{kDa})$ and active $(\sim 17 \mathrm{kDa})$ forms and Casp1 immature $(\sim 45 \mathrm{kDa})$ and active $(\sim 20$ $\mathrm{kDa})$ were analyzed in cell lysate and supernatant by western blotting. Proteins were separated by SDSpolyacrylamide gel electrophoresis (15\% SDS-PAGE) and transferred to nitrocellulose membranes (Amersham Pharmacia Biotech - GE10600002). Membranes were incubated for $2 \mathrm{~h}$ at room temperature with blocking buffer, followed by incubation with indicated primary antibodies: goat antibody to IL-1 $\beta$ p35/p-17 (1:200, Sigma Aldrich, cat. n. I3767), rat monoclonal antibody to caspase-1 p45/p20 (1: 400, Genentech, 4B4), goat antibody to ASC (p25) (1:500, Santa Cruz Biotechnology, SC- Cat. N $\left.{ }^{\circ} 33,958\right)$, rabbit antibody to phospo-Syk (p72) (11,000, Invitrogen, MA514918), rabbit antibody to Total Syk p72 (11,000, Invitrogen, PA5-17812), mouse anti- $\beta$-Actin $(11,000, C 4$, Santa Cruz sc-47,778). The enhanced chemiluminescence luminol reagent (Immobilon Forte Western HRP Substrate WBLUF0500, Millipore) was used for antibody detection as described in the instruction manual. Membranes were analyzed by using an imaging system Chemic Doc TM XRS + System (Bio-Rad Laboratories) to measure the intensity of the optical density of each band.

\section{Quantification of ASC specks formation}

Cells were collected from 8 to 10 -week-old transgenic ASC-mCitrine mice by flushing and retrieving RPMI from the peritoneal cavity. After washing, cell density was adjusted and $2 \times 10^{5}$ cells were transferred to an 8well chamber and incubated overnight at $37^{\circ} \mathrm{C}+5 \% \mathrm{CO}$ 2. Afterward, non-adherent cells were removed. Stimulation was performed in fresh medium with $\mathrm{Cg}(300 \mu \mathrm{g} /$ $\mathrm{mL}$ ) for $24 \mathrm{~h}$ in fresh RPMI medium. 


\section{Confocal microscopy and ASC-specking analysis}

Briefly, cells were fixed with $4 \%$ PFA and then washed with PBS. Cells from Transgenic ASC-mCitrine mice nuclear staining was performed with Hoechst (33528$3 \mu \mathrm{M})$. Representative images were acquired using Leica TCS SP5 confocal system. For ASC speck counting, the software Cell Profiler 3.1.5 was used. Nuclei and ASC specks were identified by specific threshold strategies, considering the size and signal intensity. The proportion of ASC specks/nuclei was expressed in percentage.

\section{Cg-induced colitis and samples collection}

The animals were gently restrained to immobilize the head. In the vertical position a stainless steel bulb tipped gavage needle is attached to a syringe and used to deliver the $\mathrm{Cg}(5 \%)$ directly into the stomach. The volume administered was $0.2 \mathrm{ml}$ per mice during 20 days. The body weight change was evaluated every morning before gavage and quality of stool were recorded each day. Upon completion of the protocol, all animals were used for colonoscopy examination and then sacrificed. The proximal and sigmoid colon regions were removed to procedure the histopathological and molecular analysis.

\section{Colonoscopy examination}

The protocol and images presented in this study were prepared with a flexible endoscope (Karl storz $\mathrm{GmbH} \& \mathrm{Co}$. KG Tele Pack VET X). The endoscopy system was set up before anesthetizing the animals, following the manufacturer's instructions. A video ureteroscope was used for this protocol. Previously a colon lavage with saline was performed to remove residual feces. The endoscope was inserted and recording started for imaging, where necessary air was injected with a syringe to slowly separate the intestinal walls. As the camera in progress the splenic flexure region, descending colon and rectum were examined. Spontaneous bleeding in the rectum and colon (defined as natural mucosal bleeding not associated with traumatic endoscopy), transparency of the colon wall (transparency was defined as the ability to visualize the intramural blood vessels in the surrounding viscera) and the number of focal lesions (Edematous areas, erosions, ulcers). Inflammatory characteristics were recorded using the colonic inflammation score of severity with decimal identifiers.

\section{Histological analysis and myeloperoxidase (MPO) immunostaining}

Paraffin-embedded tissue sections were cut into 4-mmthick sections and stained with hematoxylin-eosin for the histopathological examination. Inflammatory cell infiltrate into the distal colon wall was graded according to the following four-point scale: 0 , none damage; 1 , mild damage; 2, moderate damage; 3 , severe damage. Infiltration of neutrophils was also estimated by means of the immunohistochemical assay for myeloperoxidase. Paraffinembedded colon cross-sections (4-mm-thick) mounted on poly-L-lysine-coated slides were deparaffinized, rehydrated, immersed in $10 \mathrm{mmol} / \mathrm{L}$ citrate buffer, $\mathrm{pH}$ 6.0, and submitted to heat-induced epitope retrieval using a vapor lock for $40 \mathrm{~min}$. After heating, the slides were allowed to cool to room temperature and were briefly washed with a Trisbuffered saline solution. Endogenous peroxidase activity was blocked with $3 \%$ hydrogen peroxide for $15 \mathrm{~min}$. A protein block solution (Spring Bioscience, Pleasanton, CA, U.S.A.) was used to block nonspecific binding and incubated with the slides for $10 \mathrm{~min}$. Immunohistochemical staining was performed using a biotin-free polyvalent horseradish peroxidase (HRP) system (Reveal kit, Spring Bioscience). The intestinal sections were then incubated with the rabbit monoclonal anti-MPO antibody (clone EPR20257, Abcam, Cambridge, United Kingdom) as the primary antibody, diluted $1: 1000$, for $1 \mathrm{~h}$ at room temperature (approximately $25^{\circ} \mathrm{C}$ ) in a humidified chamber. After washing with phosphate-buffered saline, a secondary antibody (Reveal Kit Complement, Spring Bioscience) was applied for $10 \mathrm{~min}$. The sections were incubated with an HRP-conjugated secondary antibody (Reveal Kit HRP Conjugate, Spring Bioscience) for $15 \mathrm{~min}$ and developed with 3. 3-diaminobenzidine tetrahydrochloride (Spring Bioscience) in phosphate-buffered saline, $\mathrm{pH} 7.5$, for $5 \mathrm{~min}$. Light Mayer's hematoxylin was applied as a counterstain. The slides were then dehydrated in a series of ethanol dilutions and mounted with Permount (Fischer, Fairlawn, NJ, U.S.A.). The numbers of myeloperoxidasepositive leukocytes were counted in three separate crosssections of distal colon for each mouse. The results are expressed in neutrophil number per cross-section.

\section{MPO activity assay}

Neutrophil migration was assessed in the distal colon tissues of mice using a myeloperoxidase (MPO) kinetic colorimetric assay as previously described [12]. After 20 days $\mathrm{Cg}$-treatment, distal colon tissue were collected in $50 \mathrm{mM}$ K2HPO4 buffer ( $\mathrm{pH} 6.0$ ) containing $0.5 \%$ hexadecyltrimethylammonium bromide and kept at $280^{\circ} \mathrm{C}$ until use. The tissue were homogenized using a Polytron (PT3100) and centrifuged at $16,100 \mathrm{~g}$ for $4 \mathrm{~min}$. The resulting supernatant was assayed for MPO activity spectrophotometrically at $450 \mathrm{~nm}$ (SpectraMax, Molecular Devices, San Francisco, CA), with 3 readings in $1 \mathrm{~min}$. The MPO activity of samples was compared with a standard curve of neutrophils. Briefly, $10 \mathrm{~mL}$ of the sample was mixed with $200 \mathrm{~mL}$ of $50 \mathrm{mM}$ phosphate buffer, $\mathrm{pH} 6.0$, containing $0.167 \mathrm{mg} / \mathrm{mL}$ o-dianisidine dihydrochloride and $0.0005 \%$ hydrogen peroxide. The results are presented as MPO activity (number of neutrophils per milligram of tissue). 


\section{Statistical analysis}

Statistical analysis was performed by one-way ANOVA followed by a Holm-Sidak's post hoc test and the unpaired t-test to determine the level of statistical significance. Data are expressed as mean (SD). All western blotting image were representative of at least three independent experiments. For colitis colonoscopy score, comparison of groups was performed using appropriate non-parametric tests (Mann-Whitney U test, analysis of variance, Kruskal-Wallis test). Differences were considered statistically significant when the $p<0.05$ (" $p<0.05$; ${ }^{* *} p<0.01$; and ${ }^{*} p<0.001 ; \mathrm{ns}$, not significant). Data were plotted and analyzed with GraphPad Prism 6.0 software (GraphPad, San Diego, California, USA).

\section{Results}

Cg differentially requires TLR4 downstream signaling to secrete IL-1 $\beta$ and TNF by peritoneal macrophages

To study the molecular basis of Cg-induced macrophages production/release of IL- $1 \beta$ and TNF, firstly we characterize our in vitro model. For that, primary culture of peritoneal macrophages from naïve C57BL/6 (WT) mice was used and $\mathrm{Cg}$ induced a significant, concentration-dependent release of IL-1 $\beta$ and TNF at 6 h (Fig. 1a, b). The concentration of $300 \mu \mathrm{g} / \mathrm{ml}$ of Cg induced the peak of IL- $1 \beta$ release and was chosen as the concentration for the next experiments. The time-course of measurement revealed that IL-1 $\beta$ release increased progressively from $6 \mathrm{~h}$, peaking between 12 and $24 \mathrm{~h}$ after Cg stimulation (Fig. 1c). TNF release was also observed in the supernatant of Cg-stimulated macrophages (Fig. 1d), although the time-course shows the peak is already reached at $6 \mathrm{~h}$ after $\mathrm{Cg}$ incubation (Fig. 1d) in the absence of cytotoxicity (Fig. 1e). Given that the release of biologically active IL- $1 \beta$ require, at least, two important steps/signals, one for the formation of mRNA for pro-IL$1 \beta(I l 1 b)$ and a second step, the processing of pro-IL-1 $\beta$ (p35, $\sim 35 \mathrm{kDa})$ into a mature form $(\mathrm{p} 17, \sim 17 \mathrm{kDa})$, we next analyzed these two forms of IL- $1 \beta$ in peritoneal macrophages after $\mathrm{Cg}$ stimulation. Cg-stimulated macrophage increased $I l 1 b$ mRNA expression, which attains the maximum after $3 \mathrm{~h}$ post stimulation decreasing thereafter (Fig. 1f). In addition, western-blotting analyses of cell lysate and supernatant from $\mathrm{Cg}$-stimulated macrophages revealed a time- and compartment-dependent increase in pro-IL-1 $\beta$ (p35) and active IL-1 $\beta$ (p17) (Fig. 1g), suggesting that $\mathrm{Cg}$ alone induces the production and release of both forms of IL-1 $\beta$ by peritoneal macrophages.

We next sought to determine the molecular mechanisms underlying Cg-induced IL-1 $\beta$ by peritoneal macrophages. Initially, we evaluated the participation of TLRs (TLR2, TLR3, TLR4 and TLR5), their downstream signaling molecules (MyD88 and TRIF), as well as the CD14 co-receptor. The release of IL- $1 \beta$ was abrogated in Cg-stimulated peritoneal macrophages from $\mathrm{Tlr}^{-/-}$ and $\mathrm{Cd} 14^{-/-}$mice compared to the control group (Fig. 1h), which was also observed for TNF release (Fig. 1j). Macrophages from $\mathrm{Tlr}^{-/-}$and $\mathrm{Tlr} 5^{-/-}$mice released similar amounts of both cytokines. On the other hand, the release of IL-1 $\beta$, but not of TNF, were higher in macrophages from $\mathrm{Tlr}^{-/-}$mice (Fig. $1 \mathrm{~h}$ and j). Surprisingly, the production of TNF (Fig. 1k) was abrogated in $\mathrm{Cg}$-stimulated macrophages from $\mathrm{Myd}^{-8^{--}}$mice, whereas the production of IL- $1 \beta$ was inhibited in macrophages from Trif $^{-1}$ mice but did not change in macrophages from $\mathrm{Myd} 88^{-/-}$mice (Fig. 1i). Importantly, Cgstimulated peritoneal macrophages increase of $\mathrm{Il1b}$ mRNA expression is not observed in cells from $\mathrm{Tlr}^{-/-}$ and Trif $^{-1}$ mice, although it was similar to control group in macrophages from $\mathrm{Tlr} 2^{-/-}$mice (Fig. 11-n). To ensure that this TLR4-mediated effect is not due to $\mathrm{Cg}$ contamination with endotoxin (e.g. LPS), limulus amebocyte lysate test (LAL) was performed. The endotoxin level at $\mathrm{Cg}(300 \mu \mathrm{g} / \mathrm{ml})$ concentration was below the detection limit. Lipopolysaccharide (LPS; $0.01-1000 \mathrm{ng} / \mathrm{ml}$ ) was used as a positive control (Table 1 ). In addition, differently from we have observed with Cg, LPS alone was not able to induce the production of IL- $1 \beta$ by peritoneal macrophages, whereas both induced the production of TNF (Additional file 1). These results indicate that in response to $\mathrm{Cg}$, peritoneal macrophages are able to produce and release the pro-inflammatory cytokine IL-1 $\beta$, which, at least the mRNA for this cytokine depends on an unexpected TLR4/TRIF signaling pathway. Conversely, Cg-induced TNF release by peritoneal macrophages depends on the TLR4/MyD88 signaling. Noteworthy, TLR2-dependent signaling seems to counteract post-translational mechanisms involved in the production/release of IL-1 $\beta$ by peritoneal macrophages stimulated with $\mathrm{Cg}$.

\section{Syk/ROS downstream of TRIF signaling are involved in II1b mRNA expression by Cg-stimulated macrophages}

It attempt to further understand the molecular mechanisms involved in the production of IL-1 $\beta$ by $\mathrm{Cg}$ stimulated macrophages, next, we sought to find possible mechanisms downstream to TRIF pathway. There is recent evidence suggesting reactive oxygen species (ROS) as an important driver for $I l l b$ mRNA as downstream signaling of TLRs pathway [28]. Testing this hypothesis, firstly we found that peritoneal macrophages stimulated with $\mathrm{Cg}$ increased the production of ROS (Fig. 2a). Furthermore, pretreatment of macrophages with the antioxidant, $\mathrm{N}$-acetylcysteine (NAC) inhibited both $\mathrm{Cg}$ induced IL-1 $\beta$ release and the up-regulation of its mRNA expression (Fig. $2 b$ and c), without affecting the release of TNF (Additional file 2). Connecting Cginduced TRIF signaling with ROS production in 


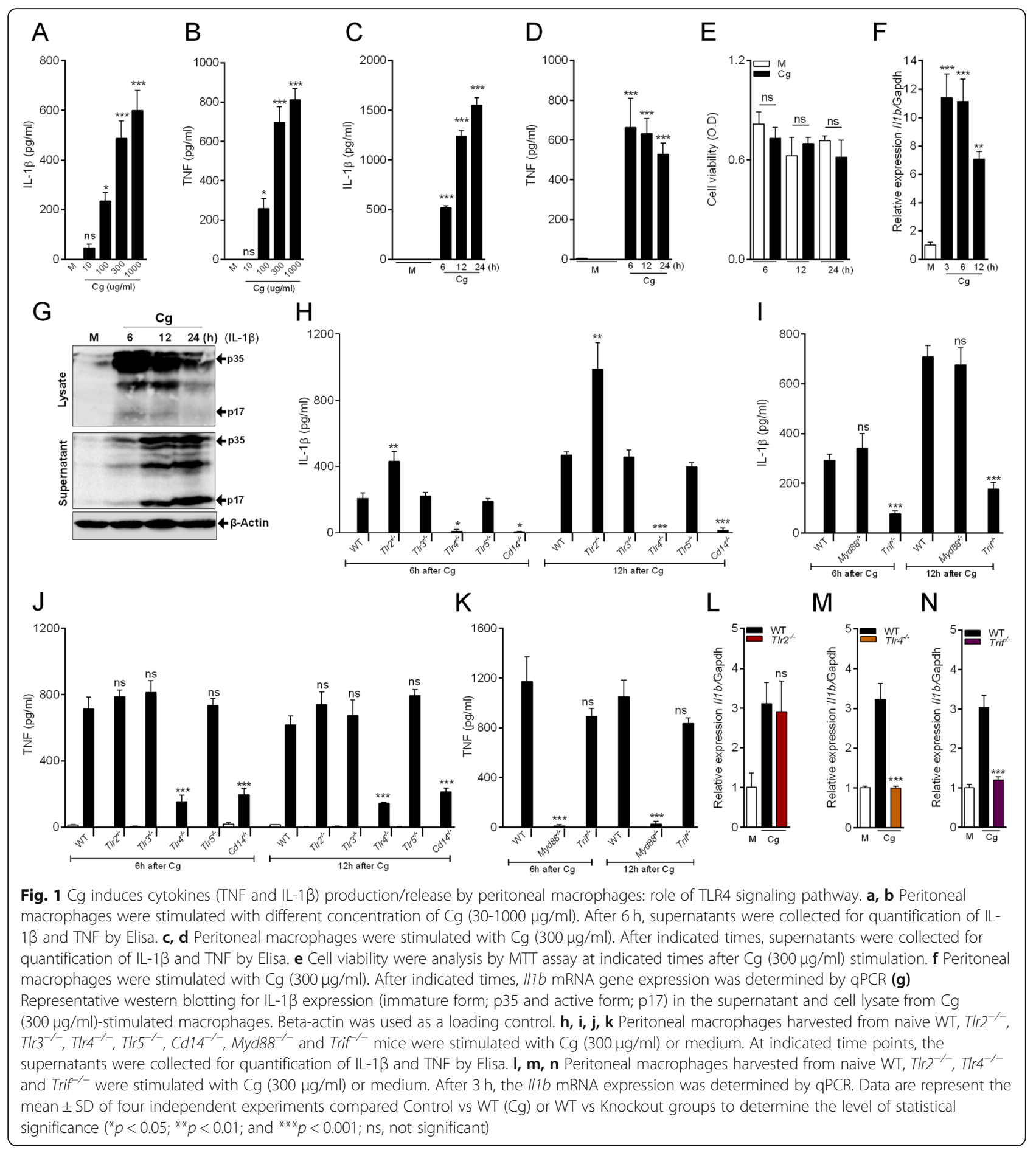

peritoneal macrophages, it was found that Cg-induced ROS production was not observed in macrophages from Trif $^{-1-}$ mice (Fig. 2d). These results indicate that TRIF/ ROS signaling mediates the induction of $I l 1 b$ mRNA in Cg-stimulated macrophages.

An important signaling pathway in macrophages responsible for ROS production is the spleen tyrosine kinase (Syk) [29]. Syk activation is upstream signaling in the production of ROS stimulated by a range of different stimuli [30-33]. Therefore, we next evaluated whether Syk pathway would be involved in the production of ROS by Cg-stimulated macrophages and consequently to drive $I l 1 b$ mRNA. We found that pharmacological inhibition of Syk (iSyk) reduced the release of IL-1 $\beta$ in Cgstimulated macrophages, which was associated with an inhibition of the expression of Illb mRNA (Fig. 2e and 
Table 1 LAL test in Cg solutions

\begin{tabular}{|c|c|c|c|c|}
\hline Samples & Presence of endotoxin & Sensitivity & Gelation occurs & Endotoxin units (EU/ml) \\
\hline Culture Medium & - & $<0,015$ & - & $\sim 1000$ \\
\hline PBS solution & - & $<0,015$ & - & $\sim 1000$ \\
\hline LPS 0,01 ng/ml & + & $>0,015$ & + & $\sim 6000$ \\
\hline LPS $0,1 \mathrm{ng} / \mathrm{ml}$ & + & $>0,015$ & + & $\sim 12,000$ \\
\hline LPS $1 \mathrm{ng} / \mathrm{ml}$ & + & $>0,015$ & + & $\sim 12,000$ \\
\hline LPS $10 \mathrm{ng} / \mathrm{ml}$ & + & $>0,015$ & + & $\sim 24,000$ \\
\hline LPS $100 \mathrm{ng} / \mathrm{ml}$ & + & $>0,015$ & + & $\sim 24,000$ \\
\hline LPS 1000 ng/ml & + & $>0,015$ & + & $\sim 24,000$ \\
\hline $\mathrm{Cg} 30 \mu \mathrm{g} / \mathrm{ml}$ & - & $<0,015$ & - & $\sim 1000$ \\
\hline $\mathrm{Cg} 100$ mg/ml & - & $<0,015$ & - & $\sim 1000$ \\
\hline $\mathrm{Cg} 300 \mu \mathrm{g} / \mathrm{ml}$ & - & $<0,015$ & - & $\sim 1000$ \\
\hline
\end{tabular}

(+) Positive or (-) Negative detection for endotoxin presence

Cg Carrageenan, LPS Lipopolysaccharide, EU/m/ corresponding endotoxin concentration

f), but does not affect TNF release (Additional file 2). Moreover, the Syk inhibitor abrogates the production of ROS in Cg-stimulated macrophages (Fig. 2g). Finally, the activation of Syk (increase in pSyk) pathway in $\mathrm{Cg}$ stimulated macrophages was not observed in Trif $^{1-}$ macrophages (Fig. 2h). Collectively these data indicate that the induction of $I l 1 b$ mRNA in Cg-stimulated peritoneal macrophages depends on a TLR4/TRIF/Syk/ROS pathway.

\section{NLRP3/ASC/Casp1 inflammasome activation is required for processing of IL-1 $\beta$ in macrophages stimulated with $\mathrm{Cg}$}

Casp1 is the major enzyme regulating the processing of pro-IL-1 $\beta$ into mature IL-1 $\beta$ in macrophages [34]. Therefore, we tested whether Casp1 is involved in the production/release of IL-1 $\beta$ by peritoneal macrophages stimulated with Cg. Firstly, we analyzed whether Cg activates Casp1 in peritoneal macrophages as detected by cleaved form (p20). We performed western blotting analysis and detected the cleaved form of Casp1 (p20) in the lysates and supernatant of Cg-stimulated macrophages (Fig. 3a). Nigericin stimulated LPS-primed macrophages was used as a positive control (Fig. 3a). Corroborating with these data, we incubated Cg-stimulated macrophages with FAM-FLICA-YVAD, a fluorescent dye that selectively binds to active Casp1. FACS analysis showed that $\mathrm{Cg}$ induced significant Casp1 activation in macrophages (Fig. $3 \mathrm{~b}$ and $\mathrm{c}$ ). Increased FAM-YVAD ${ }^{+}$positive macrophages after $\mathrm{Cg}$ stimulation can also be visualized by fluorescent microscopy (Fig. 3d). Since Cg induced the activation of Casp1 in macrophages, we determined its involvement in IL-1 $\beta$ processing. Cg-stimulated $\mathrm{C} 57 \mathrm{BL} / 6$ macrophages release IL-1 $\beta$, which was inhibited by a Casp 1 selective inhibitor (Fig. 3e) and IL-1 $\beta$ was abrogated in Cg-stimulated macrophages isolated from Casp $1 / 11^{-1-}$ mice (Fig. 3f), whereas both pro-IL1 $\beta$ (p35) and Il1b mRNA gene expression was similar to control group (Fig. $3 g$ and $h$ ). Excluding the participation of Casp11 for this process, the release of IL-1 $\beta$ by peritoneal macrophages isolated from Casp $11^{-/-}$mice and stimulated with $\mathrm{Cg}$ was similar to WT controls, whereas it still inhibited in macrophages from Casp $1^{-1-}$ Casp11 $\mathrm{Tg}$ mice (Fig. 3f). Noteworthy, none of these mouse genotypes or pharmacological treatments changed the ability of $\mathrm{Cg}$ to stimulate the production of TNF by peritoneal macrophages (Additional file 3 ). These data indicate that $\mathrm{Cg}$ induces production/release of IL-1 $\beta$ by peritoneal macrophages depends on canonical Casp1 activation, but not of Casp11.

Casp 1 activation and IL- $1 \beta$ processing are generally preceded by the assembling of inflammasome platforms, in which NLRP3 and NLRC4 inflammasomes are the most studied [35-37]. We investigated whether the production/ release of IL-1 $\beta$ by Cg-stimulated macrophages depends on one of these inflammasome platforms. We found that the release of IL-1 $\beta$ by Cg-stimulated peritoneal macrophages was not observed in macrophages from $\mathrm{Nlrp}^{-/-}$ and Pycard/Asc ${ }^{-1-}$ mice (Fig. 4a). On the other hand, no difference was observed with macrophages from $\mathrm{Nlrc}^{-1-}$ mice (Fig. 4a). The data were confirmed by western blotting analyses which showed that the levels of mature IL$1 \beta$ (p17) in the supernatant of Cg-stimulated macrophages was lower in $\mathrm{Nlrp3}^{-/-}$and Pycard ${ }^{-/-}$macrophages compared C57BL/6 controls (Fig. 4b and c). Nevertheless, TNF release (Additional file 3 ) and $I l 1 b$ mRNA remain unchanged in $\mathrm{Cg}$-stimulated macrophages from these different genotypes (Fig. 4d and e). Supporting, the role of NLRP3/ASC inflammasome for the processing of IL-1 $\beta$, we found that ASC expression was up-regulated in $\mathrm{Cg}$ stimulated peritoneal macrophages (Fig. 4f). Given that inflammasome assembly can be detected by the visualization of a dot-like structure called ASC speck [38], we performed fluorescence assay using peritoneal 

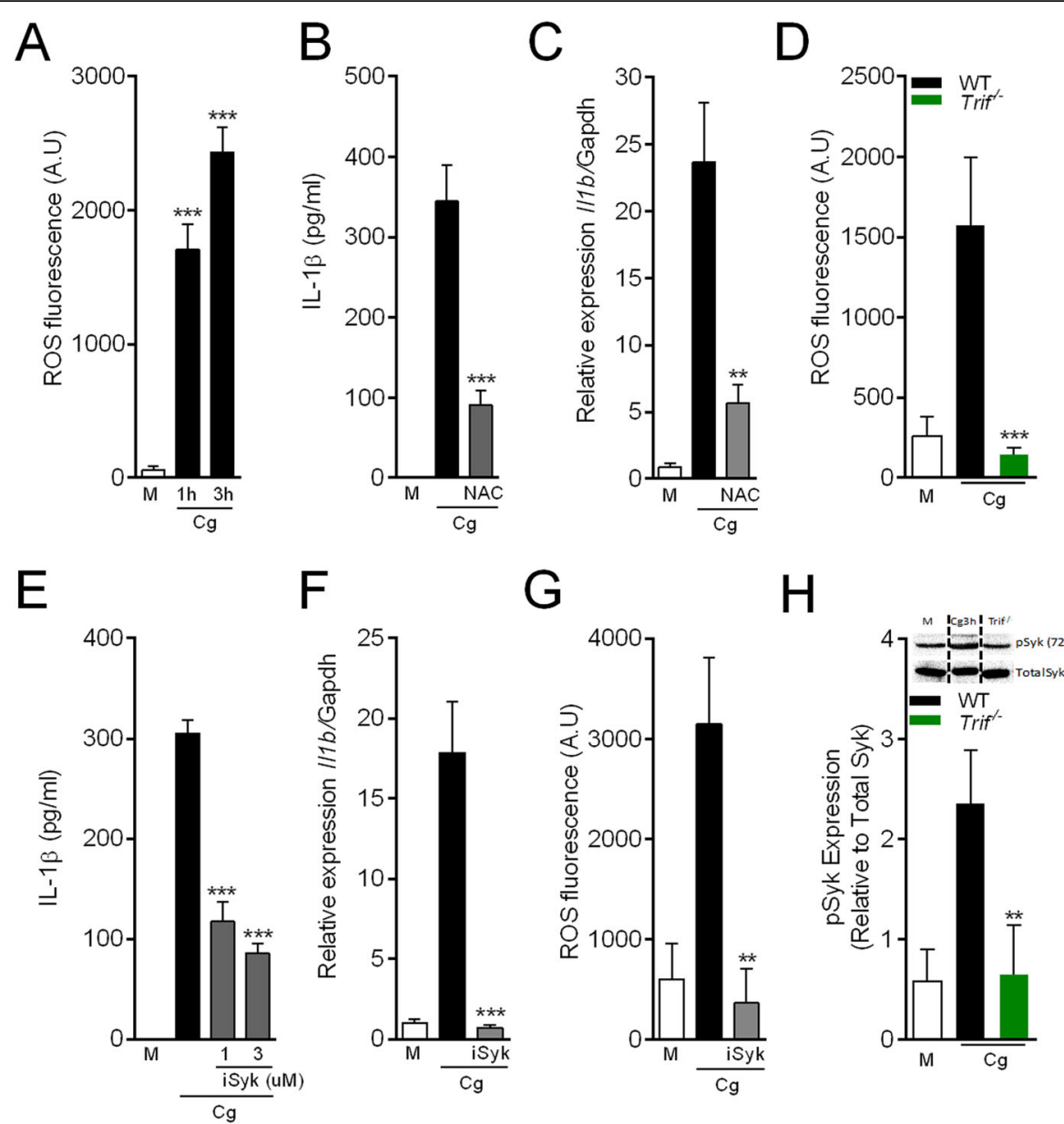

$\mathrm{H}$

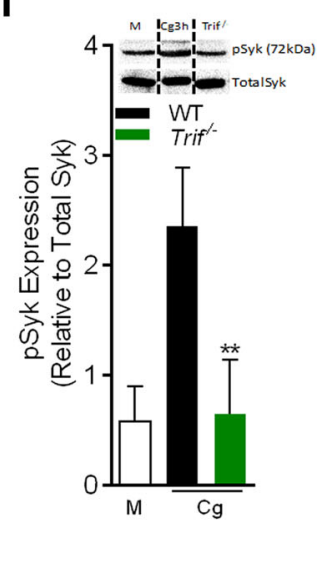

Fig. 2 Role of TRIF/Syk/reactive oxygen species on Cg-induced /11b mRNA. Peritoneal macrophages were stimulated with Cg (300 $\mu \mathrm{g} / \mathrm{ml})$ or medium. a ROS production were quantified in supernatant by the fluorescent probe assay (H2DCFDA) after indicated times. b, $\mathbf{c}$ The supernatant were collect after pre-treated cells with $\mathrm{N}$-acetylcysteine (NAC $-3 \mathrm{mM}$ ) to quantify $1 / 1 \mathrm{~b}$ mRNA gene expression by qPCR and IL-1 $\beta$ production by Elisa after $\mathrm{Cg}(6 \mathrm{~h})$. d Quantification of ROS production by (H2DCFDA probe) in cells from naive WT vs deficient for Trif ${ }^{\prime-}$ after $\mathrm{Cg}(3 \mathrm{~h})$. e, $\mathbf{f}$ Pre-treated cells with selective inhibitor of Syk (iSyk 1, $3 \mu \mathrm{M}$ ) and stimulated with $\mathrm{Cg}(6 \mathrm{~h})$ to quantify IL-1 $\beta$ by ELISA and $/ 11 \mathrm{~b}$ mRNA gene expression induced by $\mathrm{Cg}(3 \mathrm{~h})$, medium or (iSyk $3 \mu \mathrm{M}$ ). g Quantification of ROS production (H2DCFDA probe) stimulated with Cg and iSyk ( $3 \mathrm{uM}$ ) after $3 \mathrm{~h}$. $\mathbf{h}$ Western blotting analysis of (pSyk) expression compared cells from WT vs Trif $^{-1-}$. Data are represent the mean \pm SD of four independent experiments compared Control vs WT (Cg) or WT vs Knockout/Treatments groups to determine the level of statistical significance ${ }^{*} p<0.05$; ${ }^{* *} p<0.01$; and ${ }^{* * *} p<0.001$; ns, not significant)

macrophages from ASC-mCitrine Tg reporter mice [26] stimulated with Cg. Notably, we revealed an increase in ASC speck formation at $24 \mathrm{~h}$ of $\mathrm{Cg}$ stimulation compared to control group (Fig. 4g).

\section{Mechanisms of NLRP3 inflammasome activation by $\mathrm{cg}$ in macrophages}

Several intracellular mechanisms are involved in NLRP3 inflammasome activation [39-41]. Among them, potassium efflux triggers NLRP3 inflammasome activation [42]. We found that high extracellular $\mathrm{K}^{+}$levels abrogated $\mathrm{Cg}$ induced IL-1 $\beta$ released by macrophages (Fig. 5a), without affecting TNF release (Additional file 4), suggesting that canonical upstream mechanisms of NLRP3 are involved in the release of IL- $1 \beta$ by $\mathrm{Cg}$-stimulated macrophages. On the other hand, to check deeply the NLRP3 mechanism we found that Cg don't acts by changing osmolarity (Additional file 5) [43].

Extracellular ATP (eATP) acting through the purinergic receptor P2X7 (P2X7R) triggers potassium efflux in macrophages that activates NLRP3 inflammasome [44]. Therefore, the connection between P2X7R pathway for Cg-induced NLRP3 inflammasome activation and IL-1 $\beta$ processing was tested. Corroborating this hypothesis, it was found that Cg-induced IL- $1 \beta$ produced by peritoneal macrophages was reduced either in cells treated with a selective pharmacological inhibitor of P2X7R (Fig. 5b) or in macrophages from $P 2 r x 7^{-1-}$ mice (Fig. 5c). The western blotting analysis also revealed a reduction in the levels of mature IL-1 $\beta$ in the supernatant of $\mathrm{Cg}$ stimulated macrophages from $P 2 r \times 7^{-1-}$ mice compared to control (Fig. 5d). However, neither the Illb mRNA 


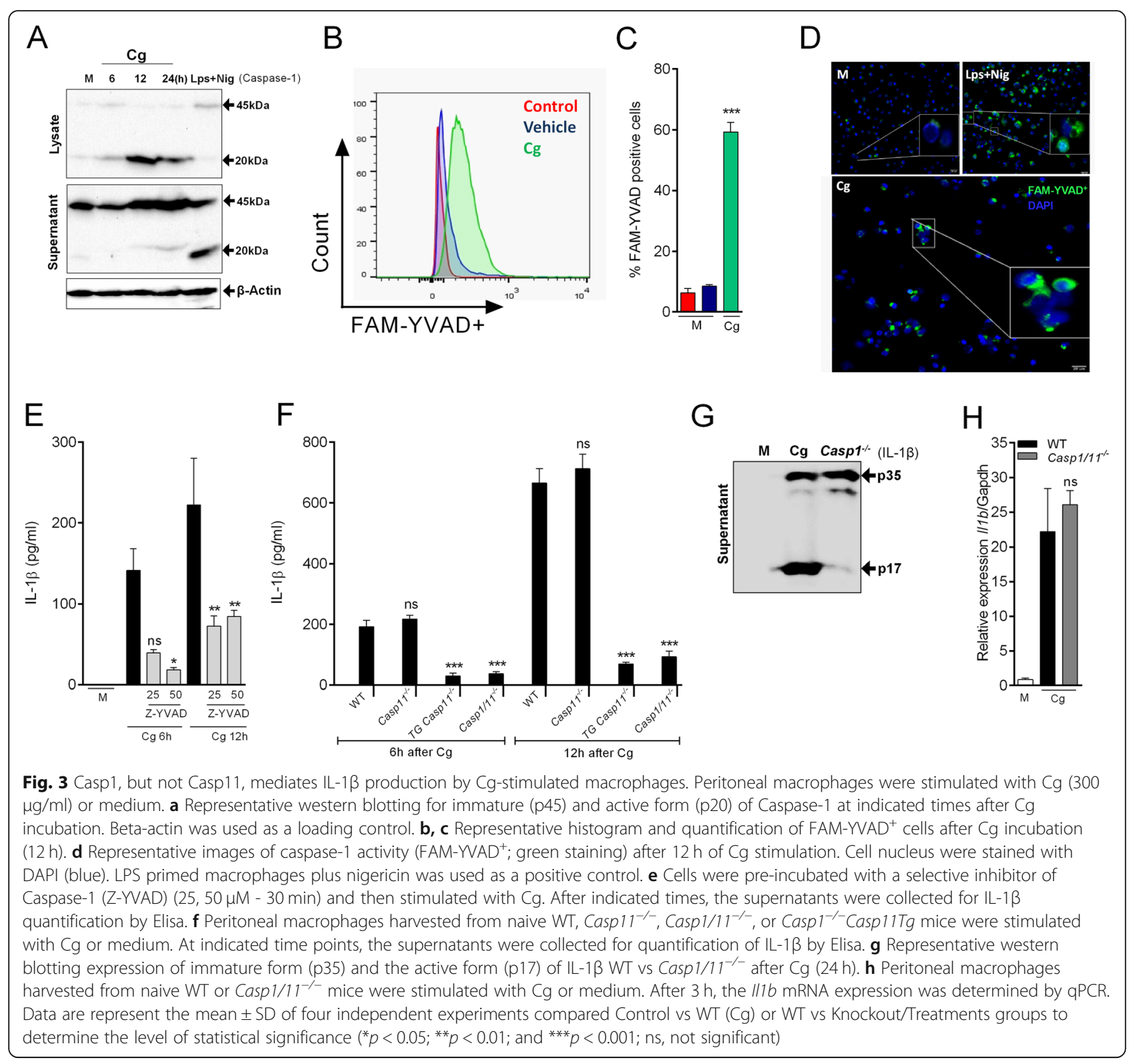

gene expression (Fig. 5e) nor the release of TNF (Additional file 6) in Cg-stimulated macrophages was changed. To support the participation of P2X7R in Cg-induced macrophage production of IL-1 $\beta$, we measured the release of eATP from peritoneal macrophages stimulated with $\mathrm{Cg}$. Indeed, there is an increase in eATP levels in Cg-stimulated macrophages, which is maximum at $6 \mathrm{~h}$ after stimulation (Fig. $5 \mathrm{f}$ ). Notably, the increase of eATP levels in Cg-stimulated macrophages was similar in macrophages from $P 2 r x 7^{-1}$ mice compared to the control group (Fig. $5 \mathrm{~g}$ ).

Pannexin-1 (Panx1), a large-pore channel, is a recognized mechanism by which intracellular ATP is released from cells $[45,46]$. Once released via Panx1, ATP acts on P2X7R to amplify potassium ion efflux that in the last instance promotes NLRP3 inflammasome activation [39].
Thus, we investigated the involvement of Panx1 channels for $\mathrm{Cg}$-induced IL- $1 \beta$ release by peritoneal macrophages. Non-selective pharmacological inhibition of Panx1 channels with carbenoxolone $(\mathrm{Cbx})$, reduced IL-1 $\beta$ release from $\mathrm{Cg}$-stimulated macrophages (Fig. 6a). These results were confirmed in $\mathrm{Cg}$-stimulated macrophages from Pan $x 1^{-/-}$mice (Fig. 6b). Noteworthy, the increase in $I l 1 b$ mRNA expression induced by $\mathrm{Cg}$ was similar in peritoneal macrophages from $\operatorname{Pan} x 1^{-1-}$ mice compared to the control group (Fig. 6c). Importantly, both pro-IL1 $\beta$ and IL-1 $\beta$ active form is reduced in macrophages supernatant from Pan $x 1^{-/-}$mice (Fig. 6d). The TNF release was not changed in Cg-stimulated macrophages from $\operatorname{Pan} x 1^{-1-}$ mice or in macrophages treated with $\mathrm{Cbx}$ (Additional file 6). Interestingly, the increase in eATP levels in Cg-stimulated 


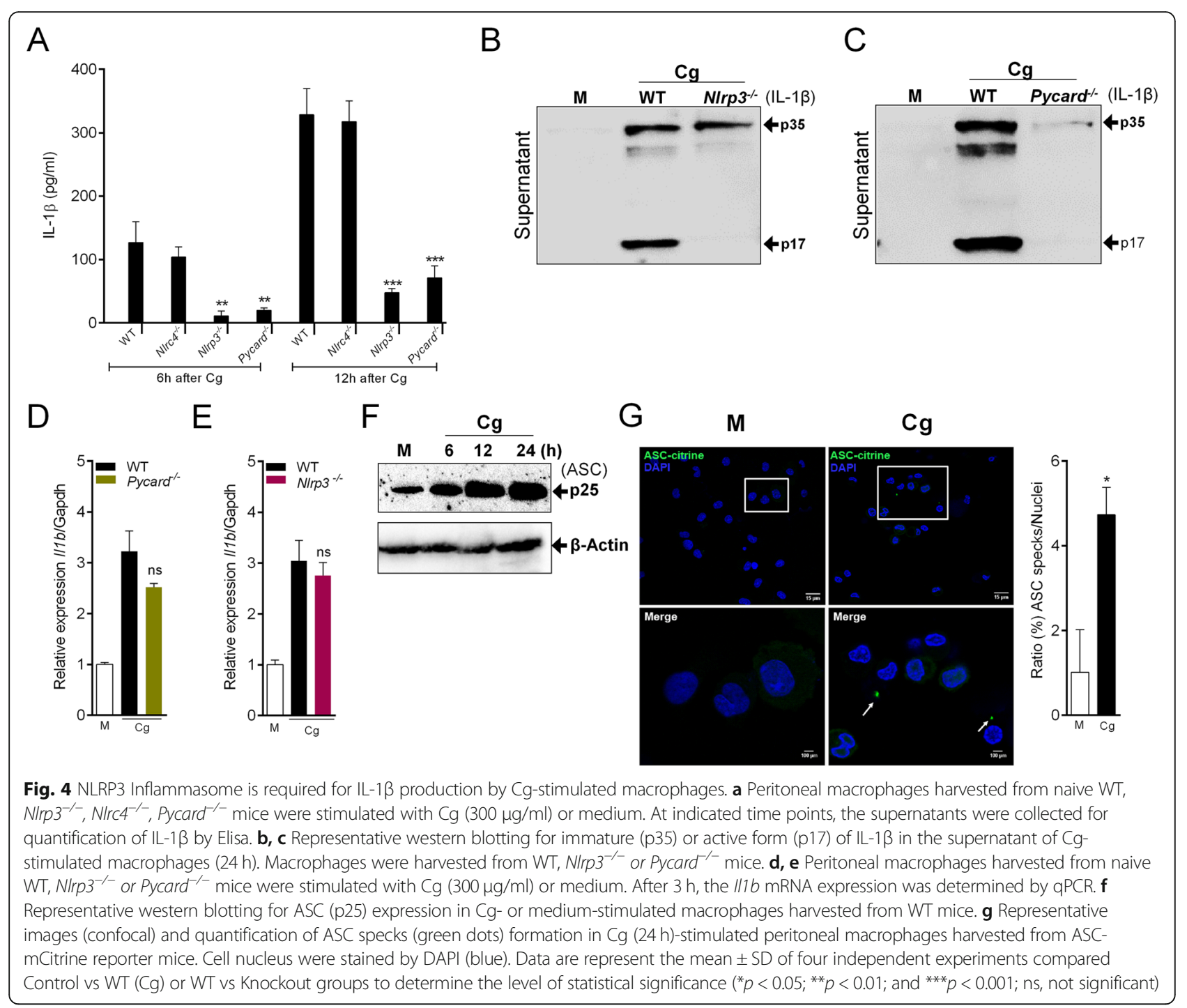

macrophages was not observed in cells from $\operatorname{Pan} x 1^{-/-}$ mice or in cells treated with $\mathrm{Cbx}$ (Fig. 6e and f). Altogether, these results indicate that Panx1/eATP/ $\mathrm{P} 2 \mathrm{X} 7 \mathrm{R} /$ potassium efflux pathway is upstream mechanisms involved in $\mathrm{Cg}$-induced IL-1 $\beta$ production by peritoneal macrophages.

\section{Cg induced experimental colitis depends on NLRP3 inflammasome}

Finally, we tested the role of NLRP3 inflammasome in a model of Cg-induced colitis [7, 47], which has been widely used in different species, including rats, mice, rabbits and guinea pigs [48-50]. Here, C57Bl6 mice received daily gavage $\mathrm{Cg}(5 \%)$ to induce the experimental colitis $[6,51,52]$. C57BL/6 mice treated with $\mathrm{Cg}$ lost body weight progressively reaching the maximum between 16 and 20 days after treatment (Fig. 7a). By contrast, $\mathrm{Nlrp3}^{-/-}$, Pycard ${ }^{-/-}$and $\mathrm{Casp1}^{-/-}$mice were protected from Cg-treatment induced weight loss (Fig. 7a). At 20 day after $\mathrm{Cg}$ treatment, high-resolution live colonoscopy analyses revealed that $\mathrm{Nlrp3}^{-/-}$Pycard $^{-/-}$ and Casp $1 / 11^{-/-}$were protected from $\mathrm{Cg}$-induced colitis (Fig. 7b-c). Histological analyses demonstrated increased number of infiltrated inflammatory cells, especially neutrophils in the crypt layer (Fig. 7d-f). The colitis severity score and neutrophils infiltration showed a significant reduction in $\mathrm{Nlrp3}^{-/-}, \mathrm{Pycard}^{-/}$and Casp1/11 $1^{-/}$mice compared to C57BL/6 mice (Fig. $7 \mathrm{~d}$ f). Quantitative analysis of MPO activity was also reduced in samples from Nlrp3 ${ }^{-/-}$, Pycard $^{-/-}$and Casp1/ $11^{-/-}$mice compared to C57BL/6 mice (Fig. 7g). Finally, we found that the level of IL-1 $\beta$ was reduced in the colon of $\mathrm{Nlrp3}^{-/-}$, Pycard ${ }^{-/}$and Casp1/11 ${ }^{-/-}$mice compared to the control animals (Fig. 7h). These results indicate that NLRP3 inflammasome activation plays a crucial role in $\mathrm{Cg}$-induced colitis in mice. 

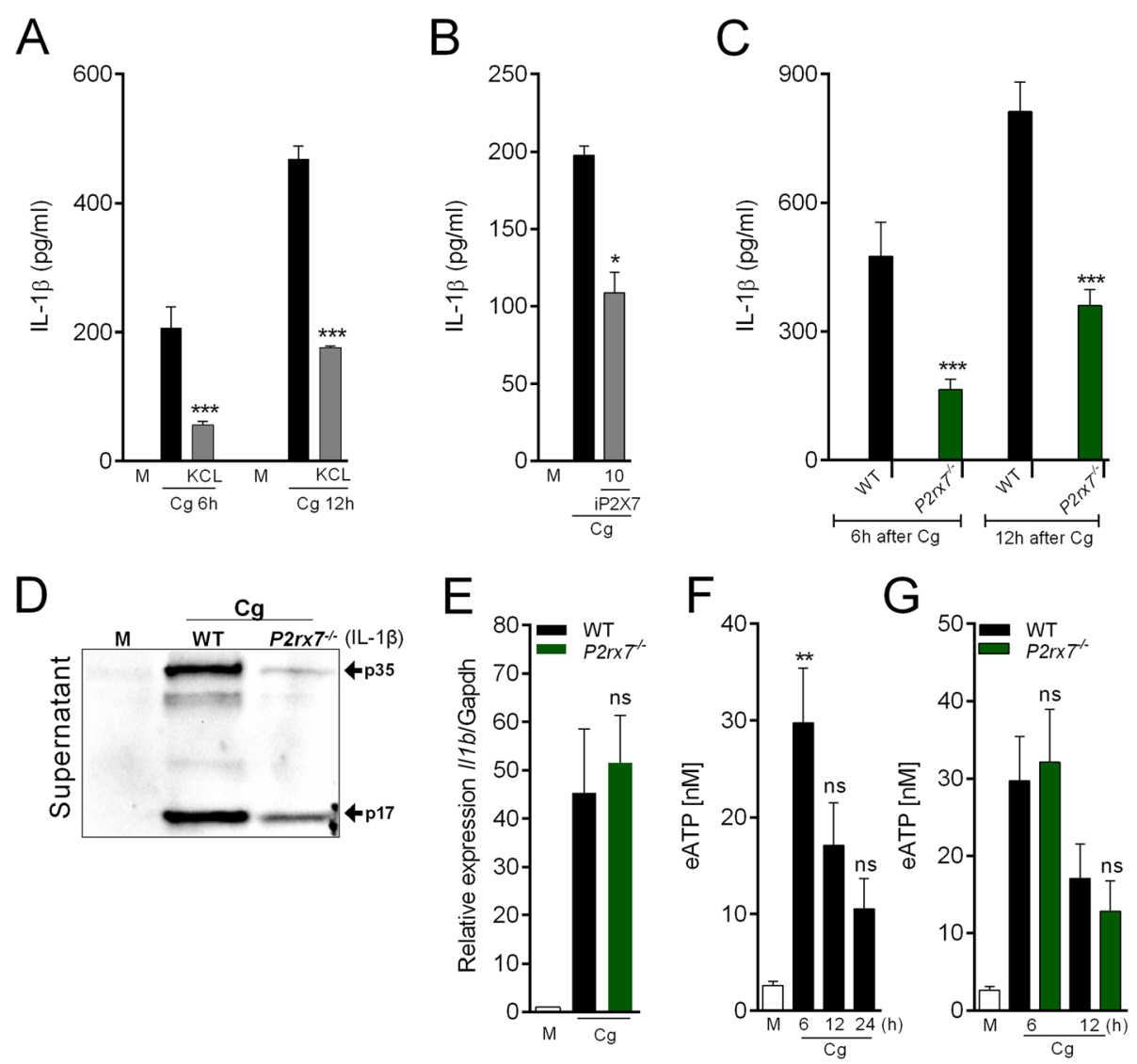

Fig. 5 Role of eATP/P2X7R in the production of IL-1 $\beta$ by Cg-stimulated macrophages. a Peritoneal macrophages were maintained in regular medium or high-concentrated $\mathrm{KCl}(25 \mathrm{mM})$ medium and then stimulated by $\mathrm{Cg}(300 \mathrm{\mu g} / \mathrm{ml})$. At indicated time points, the supernatants were collected for quantification of IL-1 $\beta$ by Elisa. b Peritoneal macrophages were pre-incubated with a selective inhibitor of P2X7R (iP2x7) (10 uM - 30 $\mathrm{min})$ and then stimulated with $\mathrm{Cg}(300 \mu \mathrm{g} / \mathrm{ml})$. After $6 \mathrm{~h}$, the supernatants were collected for $\mathrm{IL}-1 \beta$ quantification by Elisa. c Peritoneal macrophages harvested from naive WT or $P 2 x r 7^{-1-}$ mice were stimulated with $\mathrm{Cg}$ or medium. At indicated time points, the supernatants were collected for quantification of IL-1 $\beta$ by Elisa. $\mathbf{d}$ Representative western blotting for immature (p35) or active form (p17) of IL-1 in the supernatant of Cg-stimulated macrophages $\left(24 \mathrm{~h}\right.$ ). Macrophages were harvested from WT or $P 2 r \times 7^{-1-}$ mice. e Peritoneal macrophages harvested from naive WT or $P 2 r x T^{-1}$ mice were stimulated with $\mathrm{Cg}(300 \mu \mathrm{g} / \mathrm{ml})$ or medium. After $3 \mathrm{~h}$, the $\|-1 \beta \mathrm{mRNA}$ expression was determined by qPCR. f Peritoneal macrophages harvested from naive WT mice were stimulated with $\mathrm{Cg}$. At indicated times, the supernatants were collected for quantification of eATP concentration. g Peritoneal macrophages harvested from naive WT or $P 2 x r 7^{-1-}$ mice were stimulated with $\mathrm{Cg}$ or medium. At indicated times, the supernatants were collected for quantification of eATP concentration. Data are represent the mean \pm SD of four independent experiments compared Control vs WT (Cg) or WT vs Knockout/Treatments groups to determine the level of statistical significance $\left({ }^{*} p<0.05\right.$; ${ }^{* *} p<0.01$; and ${ }^{* * *} p<0.001$; ns, not significant)

\section{Discussion}

$\mathrm{Cg}$ is a linear sulfated polysaccharide extracted from seaweed. Winter and co-authors [53] observed that Cg induces foot oedema when injected in the rat's hind paw. From this, $\mathrm{Cg}$ injection in the experimental animal into different tissues has been extensively used as a model of sterile inflammation in preclinical studies $[9,10,54,55]$. However, the molecular mechanisms by which $\mathrm{Cg}$ induces inflammation is not completely elucidated. Here, we provided unraveled evidence showing that $\mathrm{Cg}$ induced TNF production by macrophages depends on activation of TLR4/CD14/MyD88 signaling pathway. On the other hand, $\mathrm{Cg}$-stimulated macrophages produce Il1b mRNA through TLR4/CD14/TRIF follow by Syk phosphorylation and ROS production. Furthermore, it was found that pro-IL- $1 \beta$ processing into mature IL- $1 \beta$ requires the activation of the NLRP3 inflammasome, which was triggered by Panx1/P2X7 receptor pathway. Finally, we demonstrated in vivo that NLRP3 inflammasome plays a crucial role in $\mathrm{Cg}$-induced colitis in mice.

Several studies related to the development of antiinflammatory drugs were based on the use of $\mathrm{Cg}$-induced inflammation as experimental models of inflammatory diseases $[56,57]$. Since the proinflammatory action of $\mathrm{Cg}$ is mainly dependent on initial activation of macrophages that in turn produce pro-inflammatory cytokines, including TNF and IL-1 $\beta[17,18,58]$ the knowledge of the molecular mechanisms of $\mathrm{Cg}$-activated macrophages 

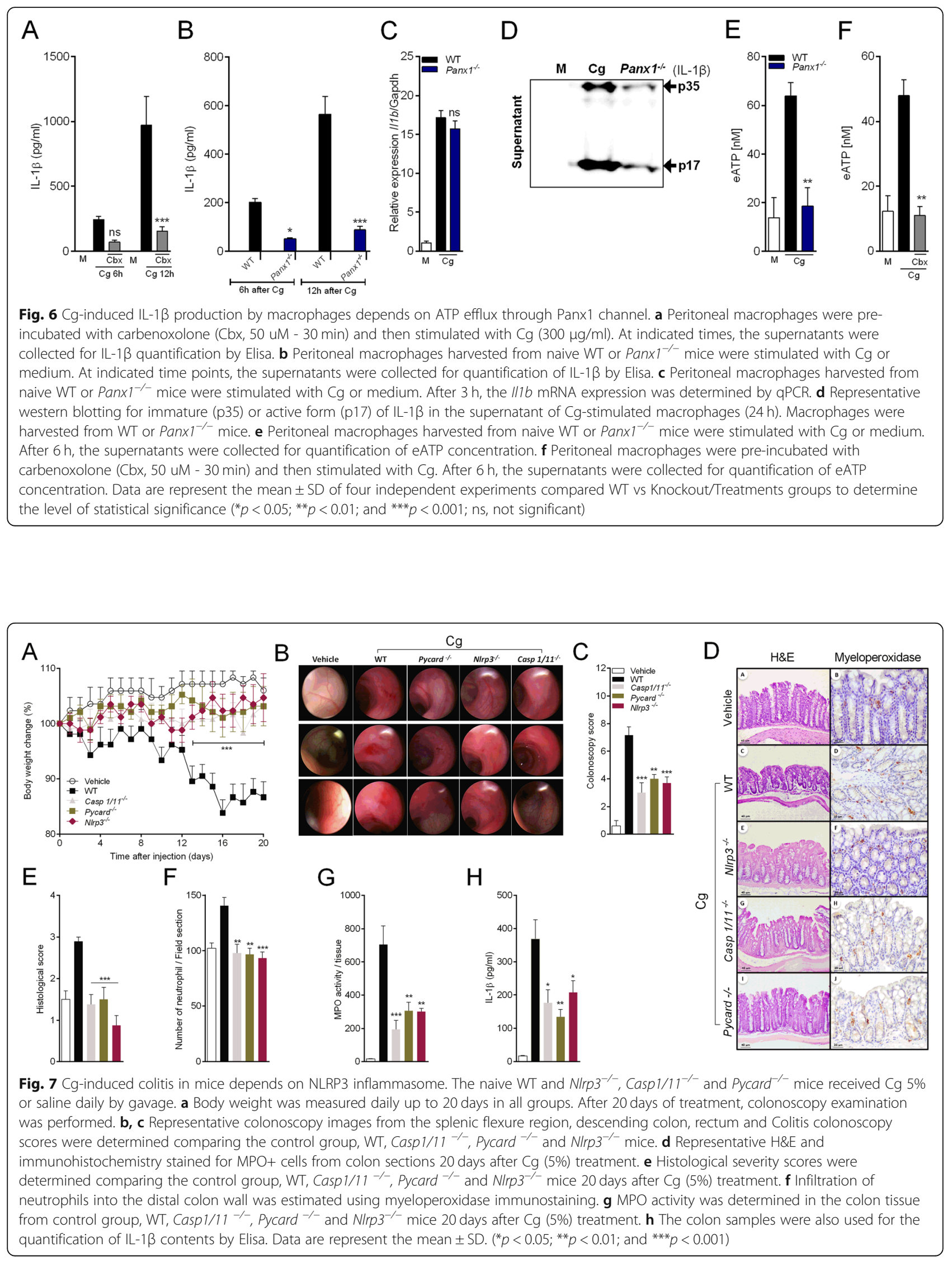
might help in the discovery of novel targets for antiinflammatory drug development. In this context, the role of TLR4 for the proinflammatory actions of $\mathrm{Cg}$ has been reported $[18,59]$. We confirmed and extended this hypothesis showing that, besides TLR4, CD14, a TLR4 adapting molecule, is also involved in Cg-induced macrophage production of cytokines. Although these evidence strongly suggest that macrophages activation by $\mathrm{Cg}$ requires the TLR4 pathway, a recent study showed Cg did not activate TLR4-HEK293 reporter cells [60]. These controversial results might be derived from different cell subtypes (macrophages X HEK293) and concentrations of Cg, which was very low in this study compared with the concentrations used in our study. Alternatively, we could not exclude the lack of expression of some molecular entity in HEK cells which might be responsible for $\mathrm{Cg}$ effect in macrophages. It is also important to point out that our TLR4 dependent effect of $\mathrm{Cg}$ is not due to contamination with LPS, which has been reported in Cg preparations [23]. Therefore, further studies will be necessary to understand whether Cg is a directly binding stimulator of TLR4, or alternatively whether $\mathrm{Cg}$ might be stimulating the release of an agonist of these receptors.

TLR4 agonists can induce activation of macrophages through MyD88-, TRIF-dependent pathways or both to produced pro-inflammatory cytokines [61-63]. Interestingly, our data suggest that $\mathrm{Cg}$ biased the production/release of TNF in a TLR4/CD14/MyD88 signaling pathway, while pro-IL-1 $\beta$ production depends on TLR4/CD14/ TRIF pathway. Although TLR4/CD14/TRIF pathway is canonical signaling for Interferon-type I production, it might be considered an atypical signaling for pro-IL- $1 \beta$ production [64]. In this context, there is evidence that the activation of TRIF pathway seems to be downstream of TLR4 internalization into the endosomal network [65]. However, the production of TRIF dependent IL- $1 \beta$ by Cg-stimulated macrophages was not reduced by an actin polymerization inhibitor (Additional file 7), ruling out that Cg-induced endocytosis of the TLR4 is essential for this signaling functions. Therefore, further studies will be necessary to completely understand the molecular basis of $\mathrm{Cg}$ stimulation of TLR4/TRIF pathway.

The signaling pathway mediated by TLR4/TRIF to the production of IL-1 $\beta$ in Cg-stimulated macrophage was demonstrated to activate tyrosine kinase Syk that in turn promotes ROS production. This signaling was previously undescribed for $\mathrm{Cg}$-induced pro-IL-1 $\beta$ production by macrophages, although the involvement of Syk in Il1b expression has been described by different stimuli, such as dengue virus, beta-glucans, serum amyloid $\mathrm{A}$ and others [66-68]. Importantly, neither Syk nor ROS signaling plays a role for $\mathrm{Cg}$-induced TNF production by macrophages, reinforcing the existence of two distinguish/ independent pathways triggered by $\mathrm{Cg} / \mathrm{TLR} 4$ that drives
TNF or IL-1 $\beta$, respectively. Although we did not investigate the final mechanisms by which $\mathrm{Cg}$-triggered ROS induces pro-IL-1 $\beta$ expression, there is recent evidence showing that ROS drive the expression of pro-IL-1 $\beta$ through an increase in the transcriptional factor HIF- $1 \alpha$ [28].

It is well accepted that IL- $1 \beta$ production depends on two distinct cellular signals [69, 70]. The first signal, which is normally driven by the activation of pattern recognition receptors (e.g. LPS through TLR4), culminates in the production of $I l 1 b$ mRNA/pro-IL-1 $\beta$ [71]. The second signal is responsible for inflammasome activation that in turn convert pro-IL- $1 \beta$ into mature IL- $1 \beta$ $[72,73]$. We showed here that $\mathrm{Cg}$ alone serves as these two signals since it was able to induce peritoneal macrophages to produce both pro-IL-1 $\beta$ and NLRP3dependent IL-1 $\beta$. Noteworthy, LPS is not able to induce mature IL- $1 \beta$ release by peritoneal macrophages, as $\mathrm{Cg}$. This might indicate that there are additional components of Cg-induced NLRP3 activation and mature IL$1 \beta$ production besides the stimulation of TLR4. Despite extensive studies on NLRP3 inflammasome activation by several cellular stimuli, $[74,75]$ its activation by $\mathrm{Cg}$ was not investigated yet. Here, we proposed that $\mathrm{Cg}$ activates this inflammasome via the convergent/canonical signal, the $\mathrm{K}+$ efflux [42]. As the main $\mathrm{K}+$ efflux upstream mechanisms for Cg-induced NLRP3 activation, it was found an important role for Panx1 and P2X7 receptors. We hypothesized that $\mathrm{Cg}$ initially promoted the opening of pannexin-1 channel for extrusion of ATP. Subsequently, ATP through P2X7 might drive $\mathrm{K}+$ efflux. This hypothesis is in accordance with the activation of NLRP3 in human monocytes by TLR2 agonists and mouse macrophages by nanoparticles [44]. At this point, an important question that emerges from our study is how $\mathrm{Cg}$ drives Panx1 activation? In this context, there is evidence that intracellular LPS stimulates NLRP3 activation through the cleavage of Panx1 [76]. Furthermore, Panx1 cleavage opens its pore promoting the release of small amounts of ATP, that in turn activates P2X7 [76]. Although the levels of eATP in peritoneal macrophages after $\mathrm{Cg}$ stimulation are relatively low compared with the levels used for the activation of P2X7 by exogenous added ATP, we can speculate that $\mathrm{Cg}$ might decrease the threshold of ATP necessary to drive P2X7 opening as observed with intracellular LPS [76].

The identification of the pivotal role of NLRP3 inflammasome for $\mathrm{Cg}$-induced macrophages production of IL$1 \mathrm{~b}$ lead us to investigate whether this molecular mechanism would be important for $\mathrm{Cg}$-induced in vivo inflammation. It has been demonstrated that Cg supplied in the drink water promotes spontaneous ulcerative lesions in the large intestine of rabbits, mice, rats and guinea pigs which resemble human ulcerative colitis [77, 
78]. Supporting, it has been shown that in human intestinal epithelial cells, carrageenan triggers an inflammatory cascade, which seems dependent on TLR4 pathway $[79,80]$. Furthermore, a randomized human trial showed that $\mathrm{Cg}$ enhances relapse in remission-patients with ulcerative colitis [81]. Our findings pointed out a crucial role for the canonical NLRP3 inflammasome in $\mathrm{Cg}$ induced colitis in mice. Although the contribution of NLRP3 for Inflammatory Bowel Disease is controversial, [82] there is evidence suggesting its pro-inflammatory role in different experimental models of colitis [83, 84]. Nevertheless, the further understanding of the molecular signaling pathways stimulated by $\mathrm{Cg}$ might be useful to the identification of new targets for treating human intestinal diseases.

\section{Conclusion}

In summary, the present study provides novel evidence for the molecular basis of Cg-induced cytokines production by macrophages. For instance, $\mathrm{Cg}$ requires TLR4/ CD14/MyD88 signaling to stimulate TNF production, whereas TLR4/CD14/TRIF/SYK/ROS promotes pro-IL$1 \beta$. Furthermore, we unravel a critical role of the canonical NLRP3 inflammasome in Cg-induced IL-1 $\beta$ secretion and colitis, which is an important discovery on the pro-inflammatory properties of this sulfated polysaccharide for pre-clinical studies.

\section{Supplementary information}

Supplementary information accompanies this paper at https://doi.org/10. 1186/s12964-020-00621-x.

Additional file 1. $\mathrm{Cg}$, but not LPS, induced $\mathrm{LL}-1 \beta$ production by naive peritoneal macrophages. (A, B) Peritoneal macrophages were stimulated with $\mathrm{Cg}(300 \mu \mathrm{g} / \mathrm{ml})$, Lipopolysaccharides (LPS - $1 \mu \mathrm{g} / \mathrm{ml}-4 \mathrm{~h})$ or medium. After treatments the supernatant were collect to quantify the $\mathrm{IL}-1 \beta$ and TNF production by Elisa. Data are represent the mean \pm SD of four independent experiments compared Control vs Treatments groups to determine the level of statistical significance $\left({ }^{*} p<0.05\right.$; ${ }^{* *} p<0.01$; *** $p<0.001 ;$ ns, not significant).

Additional file 2. Neither reactive oxygen species nor Syk are involved in TNF production/release by $\mathrm{Cg}$-stimulated macrophages. (A, B) Peritoneal macrophages were pre-incubated with $\mathrm{N}$-acetylcysteine (3 NAC - 3

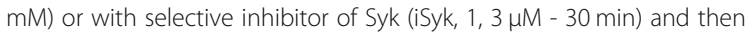
stimulated with $\mathrm{Cg}(300 \mu \mathrm{g} / \mathrm{ml})$. After $6 \mathrm{~h}$, the supernatants were collected for TNF quantification by Elisa. Data are represent the mean \pm SD of four independent experiments compared WT (Cg) vs Treatments groups to determine the level of statistical significance (ns, not significant).

Additional file 3. $\mathrm{Cg}$-induced TNF released by macrophages did not involved Casp1/11 neither Inflammasome platform. (A) Peritoneal macrophages were pre-incubated with selective inhibitor of Casp1 (Z-YVAD; 25, $50 \mu \mathrm{M}-30 \mathrm{~min})$ and then stimulated with $\mathrm{Cg}(300 \mu \mathrm{g} / \mathrm{ml})$. After indicated times, the supernatants were collected for TNF quantification by Elisa. (B, C) Peritoneal macrophages harvested from naive WT, Casp $11^{-1-}$, Casp 1/ $11^{-/-}$, Casp 11Tg, NIrp3 ${ }^{-/-}$, N/rc4 ${ }^{-/-}$, Pycard ${ }^{-/-}$mice were stimulated with $\mathrm{Cg}(300 \mu \mathrm{g} / \mathrm{ml})$ or medium. After indicated time points, the supernatants were collected for quantification of TNF by Elisa. Data are represent the mean \pm SD of four independent experiments compared WT vs Knockout/
Treatments groups to determine the level of statistical significance (ns, not significant).

Additional file 4. Potassium efflux is not involved in Cg-induced TNF production by macrophages. (A) Peritoneal macrophages were maintained in regular medium or high-concentrated $\mathrm{KCl}(25 \mathrm{mM})$ medium and then stimulated by $\mathrm{Cg}(300 \mu \mathrm{g} / \mathrm{ml})$. At indicated time points, the supernatants were collected for quantification of TNF by Elisa. Data are represent the mean \pm SD of four independent experiments compared WT (Cg) vs Treatments groups to determine the level of statistical significance (ns, not significant).

Additional file 5. Osmolarity of Cg solutions. (A) The osmolarity of the medium was measured in the presence of different concentrations of $\mathrm{Cg}$ using an osmometer.

Additional file 6 . The activation of $P 2 \times 7 / P a n \times 1$ channels is not involved in Cg-induced TNF production by macrophages. (A) Peritoneal macrophages were pre-incubated with a selective inhibitor of P2x7 (iP2x7) (10 $\mathrm{uM}-30 \mathrm{~min})$ and then stimulated with $\mathrm{Cg}(300 \mu \mathrm{g} / \mathrm{ml})$. After $6 \mathrm{~h}$, the supernatants were collected for TNF quantification by Elisa. (B) Peritoneal macrophages harvested from naive WT or $P 2 r \times 7^{-1-}$ mice were stimulated with $\mathrm{Cg}(300 \mu \mathrm{g} / \mathrm{ml})$ or medium. At indicated time points, the supernatants were collected for quantification of TNF by Elisa. (C) Peritoneal macrophages were pre-incubated with carbenoxolone (Cbx, $50 \mathrm{uM}$ - $30 \mathrm{~min}$ ) and then stimulated with $\mathrm{Cg}(300 \mu \mathrm{g} / \mathrm{ml})$. At indicated times, the supernatants were collected for TNF quantification by Elisa. (D) Peritoneal macrophages harvested from naive WT or Pan $\times 1^{-1-}$ mice were stimulated with $\mathrm{Cg}(300 \mu \mathrm{g} / \mathrm{ml})$ or medium. At indicated time points, the supernatants were collected for quantification of TNF by Elisa. Data are represent the mean \pm SD of four independent experiments compared WT vs Knockout/Treatments groups to determine the level of statistical significance (ns, not significant).

Additional file 7. Role of phagocytosis on Cg-induced cytokines production by peritoneal macrophages (A, B) Peritoneal macrophages were pretreated with Cytochalasin D $(30 \mu \mathrm{g} / \mathrm{ml})$ and then stimulated by $\mathrm{Cg}$ $(300 \mu \mathrm{g} / \mathrm{ml})$. The supernatants were collected after $12 \mathrm{~h}$ of $\mathrm{Cg}$ stimulation for quantification by Elisa. Data are represent the mean \pm SD of four independent experiments compared WT $(\mathrm{Cg})$ vs Treatments groups to determine the level of statistical significance $\left({ }^{*} p<0.05 ;{ }^{* *} p<0.01 ;{ }^{* * *} p<\right.$ $0.001 ;$ ns, not significant).

\section{Abbreviations}

ATP: Adenosine triphosphate; ASC: Apoptosis-associated Speck-like protein containing a Caspase-recruitment domain; $\beta$ : Beta; Cg: Carrageenan;

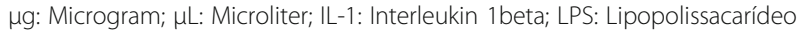
de Escherichia coli; NLRC4: IL-1ßconverting enzyme Protease-Activating Factor; NLRP3: NOD-like receptor family, pyrin domain containing 3; P2XR7: P2X purinoceptor 7; ROS: Reactive oxygen species; Syk: Spleen tyrosine kinase; TNF: Tumor necrosis factor

\section{Acknowledgements}

We thank all technical members of our laboratory and collaborators for their contributions.

\section{Authors' contributions}

$\mathrm{AHL}, \mathrm{TMC}$ wrote the manuscript. AHL, TMC, RLS, IC and BR designed provided overall guidance for the experiments. AHL, RLS, MDF, FIG, AGM, LSR, LMMM, FSR and AG performed the experiments. AHL, LSR, MDF, FIG analyses the data. DZ, BSF, FQC, JCAF, VQ, NPL intellectual contribution and reagents. All authors read and approved the final manuscript.

\section{Funding}

This work was supported by São Paulo Research Foundation (FAPESP), Brazil (grant n²013/08216-2), Center for Research in Inflammatory Disease, Brazil (grant $n^{\circ}$ 2011/19670-0), National Council for Scientific and Technological Development (CNPq), Brazil (grant $n^{\circ}$ 141150/2013-0) and Centre National de la Recherche Scientifique (CNRS) - European Regional Development Fund, France (grant $n^{\circ}$ 2016-00110366).

Availability of data and materials

All data generated or analysed during this study are included in the article. 


\section{Ethics approval and consent to participate}

The present study was approved by the Ethics Committee on Animal Experimentation of the Ribeirão Preto Medical School, University of São Paulo before the beginning of this study (Process n 180/2016).

\section{Consent for publication}

All authors approved the content of this manuscript.

\section{Competing interests}

All authors declare no conflicts and approved the content of this manuscript

\section{Author details}

'Department of Pharmacology, Ribeirão Preto Medical School, University of São Paulo, Center for Research in Inflammatory Diseases (CRID)Av. Bandeirantes 3900, 14049-900, Ribeirão Preto, SP, Brazil. ${ }^{2}$ Institute of Innate Immunity, University Hospitals, University of Bonn, 53127 Bonn, Germany. ${ }^{3}$ Department of Physics and Chemistry, University of São Paulo, Ribeirão Preto, SP, Brazil. ${ }^{4}$ Department of Cellular and Molecular Biology, Ribeirão Preto Medical School, University of São Paulo, Ribeirão Preto, SP, Brazil. ${ }^{5}$ University of Orleans and CNRS, UMR7355 Experimental and Molecular Immunology, Orleans, France. ${ }^{6}$ Department of Pathology, School of Medicine of Ribeirão Preto, University of São Paulo, Ribeirão Preto, SP, Brazil.

\section{Received: 18 September 2019 Accepted: 2 July 2020}

\section{Published online: 07 September 2020}

\section{References}

1. Jiao G, Yu G, Zhang J, Ewart HS. Chemical structures and bioactivities of sulfated polysaccharides from marine algae. Mar Drugs. 2011. https://doi. org/10.3390/md9020196

2. Necas J, Bartosikova L. Carrageenan: a review. Veterinarni Medicina. 2013. https://doi.org/10.17221/6758-VETMED.

3. Joint FAO/WHO Expert Committee on Food Additives (JECFA). Safety evaluation of certain food additives, WHO Food Additives Series 70. In: Prepared by the Seventy-ninth Meeting of the JECFA; 2015.

4. Blakemore WR. Polysaccharide ingredients: carrageenan. Ref Module Food Sci. 2015. https://doi.org/10.1016/B978-0-08-100596-5.03251-0.

5. McKim JM, et al. Critical review of Bhattacharyya et al. Nutr Healthy Aging. 2017. https://doi.org/10.3233/NHA-180051.

6. Tobacman JK. Review of harmful gastrointestinal effects of carrageenan in animal experiments. Environ Health Perspect. 2001. https://doi.org/10.1289/ ehp.01109983.

7. Benard C, Cultrone A, Michel C, Rosales C, Segain JP, Lahaye M, et al. Degraded carrageenan causing colitis in rats induces TNF secretion and ICAM-1 upregulation in monocytes through NF-kappaB activation. PLoS One. 2010. https://doi.org/10.1371/journal.pone.0008666.

8. Nicklin S, Miller E. Effect of orally administered food-grade carrageenan on antibody-mediated and cell-mediated immunity in the inbred rat. Food Chem Toxicol. 1984. https://doi.org/10.1016/0278-6915(84)90270-9.

9. Morris CJ. Carrageenan-induced paw edema in the rat and mouse. Inflamm Protoc Methods Mol Biol. 2003. https://doi.org/10.1385/1-59259-374-7:115.

10. Himes R, Lee S, McMenigall K, Russell-Jones GJ. Reduction in inflammation in the footpad of carrageenan treated mice following the topical administration of anti-TNF molecules formulated in a micro-emulsion. J Control Release. 2010. https://doi.org/10.1016/j.jconrel.2010.04.023.

11. Lopes AH, Brandolini L, Aramini A, Bianchini G, Silva RL, Zaperlon AC, et al. DF2755A, a novel non-competitive allosteric inhibitor of CXCR1/2, reduces inflammatory and post-operative pain. Pharmacol Res. 2016. https://doi.org/ 10.1016/j.phrs.2015.11.005.

12. Cunha TM, Verri WA, Jr Schivo IR, Napimoga MH, Parada CA, Poole S, et al. Crucial role of neutrophils in the development of mechanical inflammatory hypernociception. J Leukoc Biol. 2008. https://doi.org/10.1189/jlb.0907654.

13. Zarpelon AC, Cunha TM, Alves-Filho JC, Pinto LG, Ferreira SH, McInnes IB, et al. IL-33/ST2 signalling contributes to carrageenin-induced innate inflammation and inflammatory pain: role of cytokines, endothelin-1 and prostaglandin E2. Br J Pharmacol. 2013. https://doi.org/10.1111/bph.12110.

14. De Souza GE, Ferreira SH. Blockade by antimacrophage serum of the migration of PMN neutrophils into the inflamed peritoneal cavity. Agents Actions. 1985. https://doi.org/10.1007/bf01966691.
15. Cunha TM, Verri WA, Jr Silva JS, Poole S, Cunha FQ, Ferreira SH. A cascade of cytokines mediates mechanical inflammatory hypernociception in mice. Proc Natl Acad Sci USA. 2005. https://doi.org/10.1073/pnas.0409225102.

16. Lopes AH, Talbot J, Silva RL, Lima JB, França RO, Verri WA Jr, et al. Peripheral NLCR4 inflammasome participates in the genesis of acute inflammatory pain. Pain. 2015. https://doi.org/10.1097/01.j.pain.0000460322.72396.53.

17. Nacife VP, de Nazaré Correia Soeiro M, Gomes RN, D Avila H, Castro-Faria Neto HC, Meirelles MN. Morphological and biochemical characterization of macrophages activated by carrageenan and lipopolysaccharide in-vivo. Cell Struct Funct. 2004. https://doi.org/10.1247/csf.29.27.

18. Bhattacharyya S, Gill R, Ling Chen M, Zhang F, Linhardt RJ, Dudeja PK, et al. Toll-like receptor 4 mediates induction of the Bcl10-NF_B-interleukin-8 inflammatory pathway by carrageenan in human intestinal epithelial cells. J Biol Chem. 2008. https://doi.org/10.1074/jbc.M708833200.

19. Cunha L, Grenha A. Sulfated seaweed polysaccharides as multifunctiona materials in drug delivery applications mar. Drugs. 2016. https://doi.org/10. 3390/md14030042.

20. Leiro JM, Castro R, Arranz JA, Lamas J. Immunomodulating activities of acidic sulphated polysaccharides obtained from the seaweed Ulva rígida C. Agardh Int Immunopharmacol. 2007. https://doi.org/10.1016/j.intimp.2007. 02.007

21. Do H, Pyo S, Sohn EH. Suppression of iNOS expression by fucoidan is mediated by regulation of p38 MAPK, JAK/STAT, AP-1 and IRF-1, and depends on up-regulation of scavenger receptor B1 expression in TNF-aand IFN- $\gamma$-stimulated C6 glioma cells. J Nutr Biochem. 2010. https://doi.org/ 10.1016/j.jnutbio.2009.03.013.

22. Kim MH, Joo HG. Immunostimulatory effects of fucoidan on bone marrowderived dendritic cells. Immunol Lett. 2008. https://doi.org/10.1016/j.imlet 2007.10.016.

23. Tsuji RF, Hoshino K, Noro Y, Tsuji NM, Kurokawa T, Masuda T, et al. Suppression of allergic reaction by lambda-carrageenan: toll-like receptor 4/ MyD88-dependent and independent modulation of immunity. Clin Exp Allergy. 2003. https://doi.org/10.1046/j.1365-2222.2003.01575.x.

24. Teruya T, Tatemoto H, Konishi T, Tako M. Structural characteristics and in vitro macrophage activation of acetyl fucoidan from Cladosiphon okamuranus. Glycoconj J. 2009. https://doi.org/10.1007/s10719-008-9221-x.

25. Cunha TM, Talbot J, Pinto LG, Vieira SM, Souza GR, Guerrero AT, et al. Caspase-1 is involved in the genesis of inflammatory hypernociception by contributing to peripheral IL-1 $\beta$ maturation. Mol Pain. 2010. https:/doi.org/ 10.1186/1744-8069-6-63.

26. Tzeng TC, Schattgen S, Monks B, Wang D, Cerny A, Latz E, et al. A fluorescent reporter mouse for Inflammasome assembly demonstrates an important role for cell-bound and free ASC specks during in vivo infection. Cell Rep. 2016. https://doi.org/10.1016/j.celrep.2016.06.011.

27. Mosmann TJ. Rapid colorimetric assay for cellular growth and survival: Application to proliferation and cytotoxicity assays. Immunol Methods. 1983 https://doi.org/10.1016/0022-1759(83)90303-4

28. Mills EL, Kelly B, Logan A, Costa ASH, Varma M, Bryant CE, et al. Succinate dehydrogenase supports metabolic repurposing of mitochondria to drive inflammatory macrophages. Cell. 2016. https://doi.org/10.1016/j.cell.2016.08.064.

29. Underhill DM, Rossnagle E, Lowell CA, Simmons RM. Dectin-1 activates Syk tyrosine kinase in a dynamic subset of macrophages for reactive oxygen production. Blood. 2005. https://doi.org/10.1182/blood-2005-03-1239.

30. Gross H, Poeck M, Bscheider M, Dostert C, Hannesschlager N, Endres S, et al. Syk kinase signalling couples to theN/rp3 inflammasome for anti-fungal host defence. Nature. 2009. https://doi.org/10.1038/nature07965.

31. Miller YI, Choi SH, Wiesner P, Bae YS. The SYK side of TLR4: signalling mechanisms in response to LPS and minimally oxidized LDL. Br J Pharmacol. 2012. https://doi.org/10.1111/j.1476-5381.2012.02097x.

32. Lima-Junior DS, Mineo TWP, Calich VLG, Zamboni DS. Dectin-1 activation during Leishmania amazonensis phagocytosis prompts Syk-dependent reactive oxygen species production to trigger Inflammasome assembly and restriction of parasite replication. J Immunol. 2017. https://doi.org/10.4049/jimmunol.1700258.

33. Al-Harbi NO, Nadeem A, Ahmad SF, Alanazi MM, Aldossari AA, Alasmari F. Amelioration of sepsis-induced acute kidney injury through inhibition of inflammatory cytokines and oxidative stress in dendritic cells and neutrophils respectively in mice: Role of spleen tyrosine kinase signaling Biochimie. 2019. https://doi.org/10.1016/j.biochi.2018.12.014.

34. Kuida K, Lippke JÁ, Ku G, Harding MW, Livingston DJ, Su MSS, et al. Altered cytokine export and apoptosis in mice deficient in interleukin-1 $\beta$ converting enzyme. Science. 1995. https://doi.org/10.1126/science.7535475. 
35. Schroder K, Tschopp J. The inflammasomes. Cell. 2010. https://doi.org/10. 1016/j.cell.2010.01.040

36. Broz P, Dixit VM. Inflammasomes: mechanism of assembly, regulation and signalling. Nat Rev Immunol. 2016. https://doi.org/10.1038/nri.2016.58.

37. Man SM, Karki R, Kanneganti TD. Molecular mechanisms and functions of pyroptosis, inflammatory caspases and inflammasomes in infectious diseases. Immunol Rev. 2017. https://doi.org/10.1111/imr.12534.

38. Stutz A, Horvath GL, Monks BG, Latz E. ASC speck formation as a readout for inflammasome activation. In: The Inflammasome. Methods in Molecular Biology; 2013. https://doi.org/10.1007/978-1-62703-523-1_8.

39. Kanneganti M, Lamkanfi YG, Kim G, Chen JH, Park L, Franchi P, et al. Pannexin-1-mediated recognition of bacterial molecules activates the cryopyrin inflammasome independent of toll-like receptor signaling. Immunity. 2007. https://doi.org/10.1016/j.immuni.2007.03.008.

40. Takeuchi S, Akira S. Pattern recognition receptors and inflammation. Cell. 2010. https://doi.org/10.1016/j.cell.2010.01.022.

41. Shirasuna K, Karasawa T, Takahashi M. Exogenous nanoparticles and endogenous crystalline molecules as danger signals for the NLRP3 inflammasomes. J Cell Physiol. 2019. https://doi.org/10.1002/jcp.27475.

42. Muñoz-Planillo R, Kuffa P, Martinez-Colon G, Smith BL, Rajendiran T, Nuñez G. $\mathrm{K}^{+}$efflux is the common trigger of NLRP3 inflammasome activation by bacterial toxins and particulate matter. Immunity. 2013. https://doi.org/10. 1016/.j.immuni.2013.05.016.

43. Compan V, Baroja-Mazo A, López-Castejón G, Gomez AL, Martinez CM, Angosto $\mathrm{D}$, et al. Cell volume regulation modulates NLRP3 inflammasome activation. Immunity. 2012. https://doi.org/10.1016/j.immuni.2012.06.013.

44. Parzych K, Zetterqvist AV, Wright WR, Kirkby NS, Mitchell JÁ, Paul-Clark MJ. Differential role of pannexin-1/ATP/P2X $X_{7}$ axis in IL-1 $\beta$ release by human monocytes. FASEB J. 2017. https://doi.org/10.1096/fj.201600256.

45. Pelegrin P, Surprenant A. Pannexin-1 mediates large pore formation and interleukin-1 beta release by the ATP-gated P2X7 receptor. EMBO J. 2006. https://doi.org/10.1038/sj.emboj.7601378.

46. Hung SC, Choi CH, Said-Sadier N, Johnson L, Atanasova KR, Sellami H, et al. P2X4 assembles with P2X7 and pannexin-1 in gingival epithelial cells and modulates ATP-induced reactive oxygen species production and inflammasome activation. PLoS One. 2013. https://doi.org/10.1371/journal. pone.0070210.

47. Hirota SA, Ng J, Lueng A, Khajah M, Parhar K, Li Y, et al. NLRP3 inflammasome plays a key role in the regulation of intestinal homeostasis. Inflamm Bowel Dis. 2010. https://doi.org/10.1002/ibd.21478.

48. Kitano A, Matsumoto T, Hiki M, Hashimura H, Yoshiyasu K, et al. Epithelial dysplasia of the rabbit colon induced by degraded carrageenan. Cancer Res. 1986:46:1374-6

49. Marcus AJ, Marcus SN, Marcus R, Watt J. Rapid production of ulcerative disease of the colon in newly-weaned guinea-pigs by degraded carrageenan. J Pharm Pharmacol. 1989. https://doi.org/10.1111/j.2042-7158. 1989.tb06493.x.

50. Shang Q, Sun W, Shan X, Jiang H, Cai C, Hao J, et al. Carrageenan-induced colitis is associated with decreased population of anti-inflammatory bacterium, Akkermansia muciniphila, in the gut microbiota of C57BL/6J mice. Toxicol Lett. 2017. https://doi.org/10.1016/j.toxlet.2017.07.904.

51. Marcus R. Harmful effects of carrageenan fed to animals. Cancer Detect Prev. 1981:4:129-34.

52. Sharratt M, Grasso P, Carpanini F, Gangolli SD. Carrageenan ulceration as a model for human ulcerative colitis. Lancet. 1971:1:192-3.

53. Winter CA, Risley EA, Nuss GW. Carrageenin-induced edema in hind paw of the rat as an assay for antiinflammatory drugs. Proc Soc Exp Biol Med. 1962; 111(3):544-7.

54. Herisson F, Frodermann V, Courties G, Rohde D, Sun Y, Vandoorne K, et al. Direct vascular channels connect skull bone marrow and the brain surface enabling myeloid cell migration. Nat Neurosci. 2018. https://doi.org/10.1038/ s41593-018-0213-2.

55. Dyer DP, Medina-Ruiz L, Bartolini R, Schuette F, Hughes CE, Pallas K, et al. Chemokine receptor redundancy and specificity are context dependent. Immunity. 2019. https://doi.org/10.1016/.jimmuni.2019.01.009.

56. Sugishita E, Amagaya S, Ogihara Y. Antiinflammatory testing methods: comparative evaluation of mice and rats. J Pharmacobio-Dynamics. 1981;8: $565-75$

57. Jain NK, Patil CS, Singh A, Kulkarni SK. A simple technique to evaluate inflammatory pain along with anti-inflammatory studies in carrageenaninduced paw edema. Indian J Pharmacol. 2001;33:114-5.
58. Shu Y, Liu XB, Ma XH, Gao J, He W, Cao XY, et al. Immune response mechanism of mouse monocytes/macrophages treated with $\mathrm{k}$-carrageenan polysaccharide. Environ Toxicol Pharmacol. 2017. https://doi.org/10.1016/j. etap.2017.06.010.

59. Schepetkin A, Quinn MT. Botanical polysaccharides: macrophage immunomodulation and therapeutic potential Int. Immunopharmacol. 2006. https://doi.org/10.1016/j.intimp.2005.10.005.

60. McKim JM, Wilga PC, Pregenzer JF, William R. Blakemore the common food additive carrageenan is not a ligand for Toll-Like- Receptor 4 (TLR4) in an HEK293-TLR4 reporter cell-line model. Food Chem Toxicol. 2015. https://doi. org/10.1016/j.fct.2015.01.003.

61. Yamamoto M, Sato S, Hemmi H, Hoshino K, Kaisho T, Sanjo H, et al. Role of adaptor TRIF in the MyD88-independent toll-like receptor signaling pathway. Science. 2003. https://doi.org/10.1126/science.1087262.

62. Delgado MA, Elmaoued RA, Davis AS, Kyei G, Deretic V. Toll-like receptors control autophagy. EMBO J. 2008. https://doi.org/10.1038/emboj.2008.31.

63. Gurung P, Kanneganti TD. Novel roles for caspase-8 in IL-1 $B$ and inflammasome regulation. Am J Pathol. 2015. https://doi.org/10.1016/j. ajpath.2014.08.025

64. Gaidt MM, Ebert TS, Chauhan D, Schmidt T, Schmid-Burgk JL, Rapino F, et al. Human monocytes engage an alternative inflammasome pathway. Immunity. 2016. https://doi.org/10.1016/j.immuni.2016.01.012.

65. Zanoni I, Ostuni R, Marek LR, Barresi S, Barbalat R, Barton GM, et al. CD14 controls the LPS-induced endocytosis of toll-like receptor 4. Cell. 2011. https://doi.org/10.1016/j.cell.2011.09.051.

66. Callaway JB, Smith SA, McKinnon KP, de Silva AM, Crowe JE Jr, Ting JP. Spleen tyrosine kinase (Syk) mediates IL-1 $\beta$ induction by primary human monocytes during antibody-enhanced dengue virus infection. J Biol Chem. 2015. https://doi.org/10.1074/jbc.M115.664136.

67. Kankkunen P, Teirilä L, Rintahaka J, Alenius H, Wolff H, Matikainen S. (1,3)Beta-glucans activate both dectin-1 and NLRP3 inflammasome in human macrophages. J Immunol. 2010. https://doi.org/10.4049/jimmunol.0903019.

68. Migita K, Izum Y, Jiuchi Y, Kozuru H, Kawahara C, Nakamura M, et al. Serum amyloid a induces NLRP-3-mediated IL-1 $\beta$ secretion in neutrophils. PLoS One. 2014. https://doi.org/10.1371/journal.pone.0096703.

69. Latz E, Xiao TS, Stutz A. Activation and regulation of the inflammasomes. Nat Rev Immunol. 2013. https://doi.org/10.1038/nri3452.

70. Guo H, Callaway JB, Ting JPY. Inflammasomes: mechanism of action, role in disease, and therapeutics. Nat Med. 2015. https://doi.org/10.1038/nm.3893.

71. Lamkanfi M, Dixit VM. Mechanisms and functions of inflammasomes. Cell. 2014. https://doi.org/10.1016/j.cell.2014.04.007.

72. Martinon F, Burns K, Tschopp J. The inflammasome: a molecular platform triggering activation of inflammatory caspases and processing of proll-beta. Mol Cell. 2014. https://doi.org/10.1016/S1097-2765(02)00599-3.

73. Gong YN, Wang X, Wang J, Yang Z, Li S, Yang J, et al. Chemical probing reveals insights into the signaling mechanism of inflammasome activation. Cell Res. 2010. https://doi.org/10.1038/cr.2010.135.

74. Yang $Y$, Wang $H$, Kouadir M, Song $H$, Shi F. Recent advances in the mechanisms of NLRP3 inflammasome activation and its inhibitors. Cell Death Dis. 2019. https://doi.org/10.1038/s41419-019-1413-8.

75. He Y, Hara H, Núñez G. Mechanism and regulation of NLRP3 Inflammasome activation. Trends Biochem Sci. 2016. https://doi.org/10.1016/j.tibs.2016.09.002.

76. Yang D, He Y, Muñoz-Planillo R, Liu Q, Núñez G. Caspase-11 requires the pannexin-1 channel and the purinergic P2X7 pore to mediate pyroptosis and endotoxic shock. Immunity. 2015. https://doi.org/10.1016/.jmmuni.2015. 10.009 .

77. Watt J, Marcus R. Carrageenan-induced ulceration of the large intestine in the Guinea pig. Gut. 1971;12(2):164-71.

78. Martino JV, Van Limbergen J, Cahill LE. The role of carrageenan and carboxymethylcellulose in the development of intestinal inflammation. Front Pediatr. 2017. https://doi.org/10.3389/fped.2017.00096.

79. Borthakur A, Bhattacharyya S, Dudeja PK, Tobacman JK. Carrageenan induces interleukin-8 production through distinct Bcl10 pathway in normal human colonic epithelial cells. Am J Physiol Gastrointest Liver Physiol. 2007. https://doi.org/10.1152/ajpgi.00380.2006.

80. Choi HJ, Kim J, Park SH, Do KH, Yang H, Moon Y. Pro-inflammatory NFkappaB and early growth response gene 1 regulate epithelial barrier disruption by food additive carrageenan in human intestinal epithelial cells. Toxicol Lett. 2012. https://doi.org/10.1016/j.toxlet.2012.04.012.

81. Bhattacharyya S, Shumard T, Xie H, Dodda A, Varady KA, Feferman L, et al. A randomized trial of the effects of the no-carrageenan diet on ulcerative 
colitis disease activity. Nutr Healthy Aging. 2017. https://doi.org/10.3233/ NHA-170023.

82. Bauer C, Duewell P, Lehr H, Endres S, Schnurr M. Protective and aggravating effects of Nirp3 Inflammasome activation in IBD models: influence of genetic and environmental factors. Dig Dis. 2012. https://doi.org/10.1159/ 000341681.

83. Dashdorj A, Jyothi KR, Lim S, Jo A, Nguyen MN, Há J, et al. Mitochondriatargeted antioxidant MitoQ ameliorates experimental mouse colitis by suppressing NLRP3 inflammasome-mediated inflammatory cytokines. BMC Med. 2013. https://doi.org/10.1186/1741-7015-11-178.

84. Wang Y, Wang H, Qiant C, Tang J, Zhou W, Liu X, et al. 3-(2-Oxo-2phenylethylidene)-2,3,6,7-tetrahydro-1 H-pyrazino [2,1-a]isoquinolin-4(11 bH)one (compound 1), a novel potent Nrf2/ARE inducer, protects against DSSinduced colitis via inhibiting NLRP3 inflammasome. Biochem Pharmacol. 2016. https://doi.org/10.1016/j.bcp.2015.11.015.

\section{Publisher's Note}

Springer Nature remains neutral with regard to jurisdictional claims in published maps and institutional affiliations.

Ready to submit your research? Choose BMC and benefit from:

- fast, convenient online submission

- thorough peer review by experienced researchers in your field

- rapid publication on acceptance

- support for research data, including large and complex data types

- gold Open Access which fosters wider collaboration and increased citations

- maximum visibility for your research: over $100 \mathrm{M}$ website views per year

At BMC, research is always in progress.

Learn more biomedcentral.com/submissions 